\title{
Chemical composition, microstructure, and hygroscopic properties of aerosol particles at the Zotino Tall Tower Observatory (ZOTTO), Siberia, during a summer campaign
}

\author{
E. F. Mikhailov ${ }^{1,2}$, G. N. Mironov ${ }^{2}$, C. Pöhlker ${ }^{1}$, X. Chi ${ }^{1}$, M. L. Krüger ${ }^{1}$, M. Shiraiwa ${ }^{1}$, J.-D. Förster ${ }^{1}$, U. Pöschl ${ }^{1}$, \\ S. S. Vlasenko ${ }^{2}$, T. I. Ryshkevich ${ }^{2}$, M. Weigand ${ }^{3}$, A. L. D. Kilcoyne ${ }^{4}$, and M. O. Andreae ${ }^{1}$ \\ ${ }^{1}$ Biogeochemistry and Multiphase Chemistry Departments, Max Planck Institute for Chemistry, Mainz, Germany \\ ${ }^{2}$ Atmospheric Physics Department, Institute of Physics, St. Petersburg State University, St. Petersburg, Russia \\ ${ }^{3}$ Modern Magnetic Systems Department, Max Planck Institute for Intelligent Systems, Stuttgart, Germany \\ ${ }^{4}$ Lawrence Berkeley National Laboratory, Berkeley, CA, USA
}

Correspondence to: E. F. Mikhailov (eugene.mikhailov@ spbu.ru)

Received: 3 February 2015 - Published in Atmos. Chem. Phys. Discuss.: 16 March 2015

Revised: 10 July 2015 - Accepted: 24 July 2015 - Published: 13 August 2015

\begin{abstract}
In this study we describe the hygroscopic properties of accumulation- and coarse-mode aerosol particles sampled at the Zotino Tall Tower Observatory (ZOTTO) in central Siberia $\left(61^{\circ} \mathrm{N}, 89^{\circ} \mathrm{E}\right)$ from 16 to 21 June 2013. The hygroscopic growth measurements were supplemented with chemical analyses of the samples, including inorganic ions and organic/elemental carbon. In addition, the microstructure and chemical compositions of aerosol particles were analyzed by x-ray micro-spectroscopy (STXM-NEXAFS) and transmission electron microscopy (TEM). A mass closure analysis indicates that organic carbon accounted for 61 and $38 \%$ of particulate matter (PM) in the accumulation mode and coarse mode, respectively. The water-soluble fraction of organic matter was estimated to be 52 and $8 \%$ of PM in these modes. Sulfate, predominantly in the form of ammoniated sulfate, was the dominant inorganic component in both size modes: $\sim 34 \%$ in the accumulation mode vs. $\sim 47 \%$ in the coarse mode.

The hygroscopic growth measurements were conducted with a filter-based differential hygroscopicity analyzer (FDHA) over the range of 5-99.4\% RH in the hydration and dehydration operation modes. The FDHA study indicates that both accumulation and coarse modes exhibit pronounced water uptake approximately at the same relative humidity $(\mathrm{RH})$, starting at $\sim 70 \%$, while efflorescence occurred at different humidities, i.e., at $\sim 35 \% \mathrm{RH}$ for submicron particles vs. $\sim 50 \% \mathrm{RH}$ for supermicron particles. This $\sim 15 \% \mathrm{RH}$
\end{abstract}

difference was attributed to higher content of organic material in the submicron particles, which suppresses water release in the dehydration experiments.

The kappa mass interaction model (KIM) was applied to characterize and parameterize non-ideal solution behavior and concentration-dependent water uptake by atmospheric aerosol samples in the 5-99.4\% RH range. Based on KIM, the volume-based hygroscopicity parameter, $\kappa_{\mathrm{v}}$, was calculated. The $\kappa_{\mathrm{v} \text {,ws }}$ value related to the water-soluble (ws) fraction was estimated to be $\sim 0.15$ for the accumulation mode and $\sim 0.36$ for the coarse mode, respectively. The obtained $\kappa_{\mathrm{v}, \mathrm{ws}}$ for the accumulation mode is in good agreement with earlier data reported for remote sites in the Amazon rain forest $\left(\kappa_{\mathrm{v}} \approx 0.15\right)$ and a Colorado mountain forest $\left(\kappa_{\mathrm{V}} \approx 0.16\right)$.

We used the Zdanovskii-Stokes-Robinson (ZSR) mixing rule to predict the chemical composition dependent hygroscopicity, $\kappa_{\mathrm{v}, \mathrm{p}}$. The obtained $\kappa_{\mathrm{v}, \mathrm{p}}$ values overestimate the experimental FDHA-KIM-derived $\kappa_{\mathrm{v} \text {,ws }}$ by factors of 1.8 and 1.5 for the accumulation and coarse modes, respectively. This divergence can be explained by incomplete dissolution of the hygroscopic inorganic compounds resulting from kinetic limitations due to a sparingly soluble organic coating. The TEM and STXM-NEXAFS results indicate that aged submicron $(>300 \mathrm{~nm})$ and supermicron aerosol particles possess core-shell structures with an inorganic core, and are enriched in organic carbon at the mixed particle surface. The direct FDHA kinetic studies provide a bulk diffusion coefficient of 
water of $\sim 10^{-12} \mathrm{~cm}^{2} \mathrm{~s}^{-1}$ indicating a semi-solid state of the organic-rich phase leading to kinetic limitations of water uptake and release during hydration and dehydration cycles.

Overall, the present ZOTTO data set, obtained in the growing season, has revealed a strong influence of organic carbon on the hygroscopic properties of the ambient aerosols. The sparingly soluble organic coating controls hygroscopic growth, phase transitions, and microstructural rearrangement processes. The observed kinetic limitations can strongly influence the outcome of experiments performed on multisecond timescales, such as the commonly applied HTDMA (Hygroscopicity Tandem Differential Mobility Analyzer) and CCNC (Cloud Condensation Nuclei Counter) measurements.

\section{Introduction}

Siberia, a vast region in central Eurasia, has been gaining growing attention from atmospheric aerosol researchers in the last few decades. The atmospheric aerosol over Siberia is of particular interest for several reasons. Firstly, biogenic emissions of volatile organic compounds (VOC) from the vast boreal taiga forest are thought to lead to the formation of secondary organic aerosol (SOA) (Tunved et al., 2006). Secondly, Siberia has been documented to be an important source region of biomass-burning aerosol particles that are distributed around the globe in the free troposphere (Conard and Ivanova, 1997; Müller et al., 2005; Warneke et al., 2009). Thirdly, Siberia is one of the few possible background regions in the Northern Hemisphere where nearpristine conditions prevail for certain periods of the year (Chi et al., 2013). Such atmospheric observations in remote areas are very important for providing a reference for evaluating anthropogenic impacts in this and other regions (Andreae, 2007; Carslaw et al., 2013; Spracklen and Rap, 2013).

Aerosols influence the radiative budget of the Earth's atmosphere in two different ways. The first is the direct effect, whereby aerosols scatter and absorb solar and thermal infrared radiation, and thus alter the radiative balance of the Earth-atmosphere system. Aerosol particles with a diameter that is comparable to the wavelength of solar radiation $(0.2-2 \mu \mathrm{m})$ are the most effective light scatterers (Waggoner et al., 1981), which makes organic carbon and some inorganic species (e.g., sulfate, nitrate, ammonium) in the submicrometer size range typically the most effective chemical components of aerosol light scattering. The second is the indirect effect, whereby aerosols modify the microphysical and hence the radiative properties and lifetime of clouds (Haywood and Boucher, 2000; Rastak et al., 2014). These indirect effects of aerosols result from their CCN (cloud condensation nuclei) and IN (ice nuclei) activity (Twomey, 1997; Ogren and Charlson, 1992).
The hygroscopic properties of atmospheric aerosol particles are vital for a proper description of these effects, since they describe how the particles interact with water vapor both under sub- and super-saturated conditions (e.g., McFiggans et al., 2006; Swietlicki et al., 2008; Rastak et al., 2014). They are thus of major importance for describing the life cycle of the aerosol and the related direct and indirect effects on climate.

The hygroscopic properties of aerosol particles in the northern European boreal forests under sub- and supersaturated conditions have been studied extensively using the Hygroscopicity Tandem Differential Mobility Analyzer (HTDMA) and size-resolved CCN counter (Hämeri et al., 2001; Ehn et al., 2007; Birmili et al., 2009; Sihto et al., 2011; Cerully et al., 2011; Kerminen et al., 2012; Paramonov et al., 2013; Jaatinen at al., 2014). These results specifically show that in summer the aerosol particles are enriched in organic species produced by biomass burning and biogenic emissions, which overall decrease their hygroscopicity and $\mathrm{CCN}$ activity when compared to other locations in Europe. In addition, due to aerosol aging (coagulation, condensation, aerosol-cloud interactions, and chemical reactions on the surface and in the aqueous phase) the growth in aerosol size from Aitken to accumulation mode leads to an increase in their hygroscopicity (Paramonov et al., 2013).

An important limitation of the commonly used HTDMA and $\mathrm{CCN}$ instruments is that they are only applicable to small particles due to the restriction of their particle size range (typically, dry diameter $<300 \mathrm{~nm}$ ). To our knowledge, no experimental data for the hygroscopic properties of the accumulation mode in the size range $0.3-1.0 \mu \mathrm{m}$ and of the coarse $(>1 \mu \mathrm{m})$ mode in the boreal environment have been presented up to now. Therefore, we have set out to investigate and characterize the hygroscopic properties of boreal aerosol particles in the growing season covering the sub- and super-micron size ranges. The hygroscopic growth measurements of aerosol particles have been performed by a filterbased differential analyzer supplemented by chemical and microstructural studies. The instrumentation and measurement procedures applied in this study are described below. To characterize the hygroscopic behavior of the aerosol particles in the 5-99.4\% RH range, we used the mass-based hygroscopicity parameter interaction model (Mikhailov et al., 2013). This model was developed to describe and parameterize the hygroscopic properties of atmospheric particles with poorly defined chemical composition. Due to the mass-based approach, it can be used to characterize partly dissolved solutes that may co-exist in metastable equilibrium with amorphous phases. As a consequence, the model can reproduce both the characteristics of water uptake under subsaturated conditions and predict their CCN properties (Mikhailov et al., 2013). 


\section{Measurements and methods}

\subsection{Sampling site and meteorological conditions}

The aerosol samples were collected from 16 to 21 June 2013 at the Zotino Tall Tower Observatory (ZOTTO) facility, which is located near the Yenisei River at the eastern edge of the western Siberia lowland in the boreal zone $\left(60.8^{\circ} \mathrm{N}\right.$, $89.4^{\circ} \mathrm{E} ; 114 \mathrm{~m}$ a.s.1.), about $600 \mathrm{~km}$ north of the closest large city, Krasnoyarsk (950 000 inhabitants). The nearest village (Zotino) is about $20 \mathrm{~km}$ in an eastern direction from the site. The heart of the station is a $301 \mathrm{~m}$ high tower, which has been designed for long-term atmospheric observations. Because of the high intake elevation, the air masses sampled at the tower are fairly representative of a very large spatial area. A more detailed description of ZOTTO is given elsewhere (Birmili et al., 2007; Heintzenberg et al., 2008; Winderlich et al., 2010).

During our sampling campaign the weather was warm and dry and did not change significantly. The average temperature and relative humidity (RH) at nighttime and at daytime were $15.2 \pm 3.2^{\circ} \mathrm{C}$ and $(84 \% \pm 10 \%)$, and $21.8 \pm 2.8^{\circ} \mathrm{C}$ and $(61 \% \pm 19 \%)$, respectively. Backward trajectories computed with the NOAA HYSPLIT model (Draxler and Rolph, 2003) were used to trace the air history (Fig. 1). The airmass origins had essentially a continental character and they were stagnant (showed a recirculation pattern), except in the period of 16-17 June, when they came from the north. Fire maps from the Moderate Resolution Imaging Spectroradiometer (MODIS) (http://rapidfire.sci.gsfc.nasa. gov) showed several fires to the east of the ZOTTO site; therefore, air masses arriving at the station from 19 to 21 June could contain accumulated combustion products.

Carbon monoxide $(\mathrm{CO})$ is used as a transport tracer for pollutant plumes. $\mathrm{CO}$ mixing ratios in air sampled from $300 \mathrm{~m}$ were measured by UV resonance fluorescence, using a Fast-CO-Monitor (model AL 5002, Aerolaser GmbH, Germany). Details of the experimental setup and calibration are described elsewhere (Chi et al., 2013). The CO mixing ratios observed during the sampling campaign are shown in Table 1 . The daily average $\mathrm{CO}$ values correlate well with the backward trajectories and MODIS AOD product. Thus the elevated $\mathrm{CO}$ observed from 19 to 20 June can be attributed to air masses that passed over wildfires located to the east of the site (Fig. 1). Overall, during the sampling campaign the average $\mathrm{CO}$ mixing ratio was $\sim 113 \mathrm{ppb}$, which corresponds to "background" conditions in June at the ZOTTO site (Chi et al., 2013). Using the definition of Andreae (2007) and Chi et al. (2013), we refer to "background" conditions as an atmospheric state without the detectable influence of local or regional pollution sources but affected by emissions from natural origin as well as pollution transported from very distant sources.
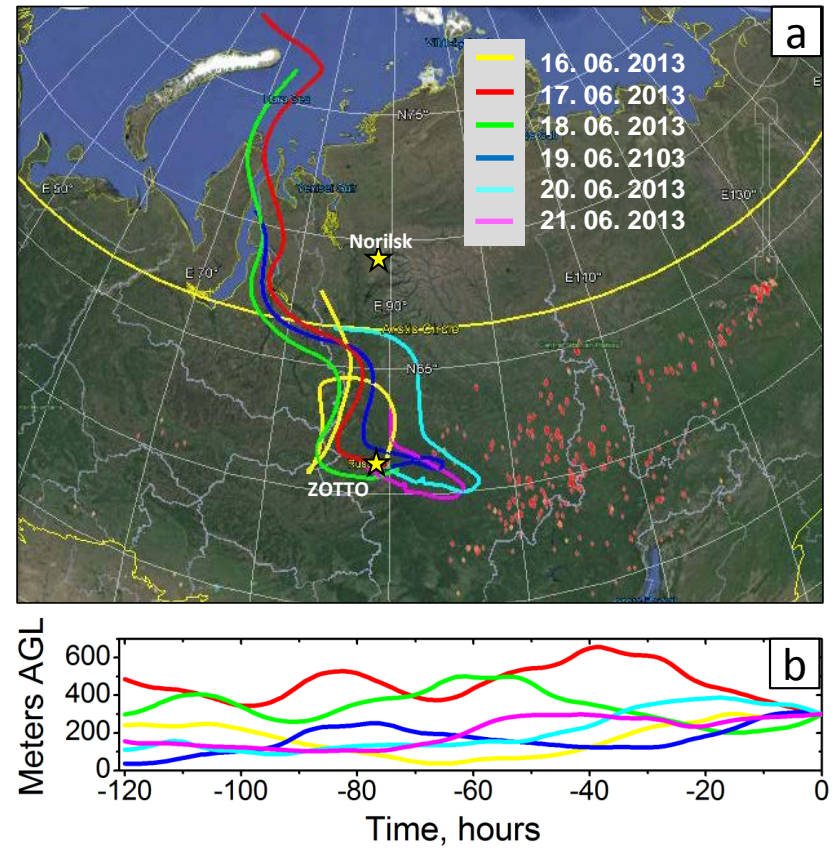

Figure 1. (a) $120 \mathrm{~h}$ HYSPLIT air-mass backward trajectories during the sampling period at ZOTTO at $300 \mathrm{~m}$ from 16 to 21 June 2013 and (b) their height above ground level (a.g.l.). Red dots indicate the fire locations within the sampling period.

\subsection{Sampling}

Ambient air was sampled through a stainless steel inlet pipe reaching to the top of the tower at $300 \mathrm{~m}$ above ground with an internal diameter of about $2.9 \mathrm{~cm}$, which was designed for a laminar nominal sampling flow of $40 \mathrm{~L} \mathrm{~min}^{-1}$ (Birmili et al., 2007). Pre-installation calibration showed that particles with diameter $D_{\mathrm{p}}>50 \mathrm{~nm}$ are nearly perfectly transmitted through this pipe (Heintzenberg et al., 2008). Additional test measurements with supermicron aerosol particles have shown that the upper transmission size limit for the inlet system was $\sim 10 \mu \mathrm{m}$.

Aerosols were collected on quartz fiber filters (2500QATUP, Pallflex) and Teflon-coated fiber glass filters (T60A20, Pallflex). The $47 \mathrm{~mm}$ quartz filters were used for organic carbon (OC) and elemental carbon (EC) analysis, while the $13 \mathrm{~mm}$ T60A20 filters were used for ion analysis and hygroscopic study. The $13 \mathrm{~mm}$ Teflon filters were loaded by passing an airflow of $10 \mathrm{~L} \mathrm{~min}^{-1}$ through a rotating Micro-Orifice Uniform Deposit Impactor (MOUDI, model 125R). Each filter was placed under an Al substrate having a $12 \mathrm{~mm}$ central hole. Two impactor stages (I) and (II) (original numeration -5 and 9) were used to collect the coarse $(>1 \mu \mathrm{m})$ and accumulation (0.1-1 $\mu \mathrm{m})$ aerosol size modes. On the quartz filters, aerosol particles were collected directly from the inlet line using a home-made sampler at a flow rate of $20 \mathrm{~L} \mathrm{~min}^{-1}$. The MOUDI and OC/EC filter sampling were conducted for a period of $130 \mathrm{~h}$. 
Table 1. CO mixing ratios (ppb) during the sampling periods on the different substrates.

\begin{tabular}{|c|c|c|c|}
\hline Sampling substrate & Methods and objectives & $\begin{array}{l}\text { Sampling dates and } \\
\text { times (UTC+7) } \\
\text { in June } 2013\end{array}$ & $\begin{array}{l}\mathrm{CO} \\
(\mathrm{ppb})\end{array}$ \\
\hline $\begin{array}{l}\text { Teflon-coated filters } \\
\text { T60A20 } \\
\text { Quartz filters } \\
\text { 2500QAT-UP }\end{array}$ & $\begin{array}{l}\text { FDHA - hygroscopic- } \\
\text { ity } \\
\text { Chromatography - } \\
\text { ions } \\
\text { SunSet - OC/EC }\end{array}$ & $\begin{array}{l}16 \\
17 \\
18 \\
19 \\
20 \\
21\end{array}$ & $\begin{array}{l}\text { Daily average } \pm 1 \mathrm{SD} \\
108 \pm 4 \\
104 \pm 1 \\
113 \pm 4 \\
120 \pm 2 \\
123 \pm 3 \\
109 \pm 1 \\
\text { Average during } \\
\text { sampling period: } \\
113 \pm 8\end{array}$ \\
\hline $\mathrm{Si}_{3} \mathrm{~N}_{4}$ membrane & $\begin{array}{l}\text { X-ray micro- } \\
\text { spectroscopy - } \\
\text { microstructure and } \\
\text { elemental maps }\end{array}$ & $\begin{array}{l}1521: 17 \\
1814: 41 \\
2409: 00 \\
2614: 27\end{array}$ & $\begin{array}{l}\text { During sampling time } \\
110 \pm 1 \\
116 \pm 1 \\
93 \pm 1 \\
93 \pm 1\end{array}$ \\
\hline $\begin{array}{l}3 \mathrm{~mm} \text { carbon-coated } \mathrm{Cu} \\
\text { grids }\end{array}$ & TEM - microstructure & $\begin{array}{l}2009: 26 \\
2115: 16\end{array}$ & $\begin{array}{l}120 \pm 1 \\
110 \pm 1\end{array}$ \\
\hline
\end{tabular}

The exposed filters were sealed in aluminum foil and then placed in Ziploc bags. The samples were stored at $4{ }^{\circ} \mathrm{C}$ before being analyzed, excluding the travel time from the station to the laboratory $(\sim 48 \mathrm{~h})$. The aerosol mass concentrations were determined gravimetrically using a MettlerToledo micro balance model XP6 with $0.6 \mu \mathrm{g}$ sensitivity. Before being weighed, the filters were equilibrated for $24 \mathrm{~h}$ at a constant temperature of $23^{\circ} \mathrm{C}$ and a relative humidity between 35 and $45 \%$. Each filter was weighed at least three times before and after sampling. An anti-static UElectrode (Mettler-Toledo) was used to discharge samples before weighing. The uncertainty (1 standard deviation) for PM determination is estimated to be 3.5 and $1 \mu \mathrm{g}$, for $47 \mathrm{~mm}$ quartz filters and $13 \mathrm{~mm}$ T60A20 filters, respectively.

Aerosol samples for x-ray micro-spectroscopy were collected using a homemade single stage impactor, which was operated at a flow rate of $1 \mathrm{~L} \mathrm{~min}^{-1}$ and a corresponding $50 \%$ size cut-off of about $550 \mathrm{~nm}$. Particles below this nominal cut-off are not deposited quantitatively; however, a certain fraction is still collected via diffusive deposition and is therefore available for the STXM analysis. Aerosol particles were collected onto width silicon nitride substrates $\left(\mathrm{Si}_{3} \mathrm{~N}_{4}\right.$, membrane $500 \mu \mathrm{m}$, membrane thickness $100 \mathrm{~nm}$, Silson Ltd., Northhampton, UK) for short sampling periods ( $20 \mathrm{~min})$, which ensures an appropriately thin particle coverage on the substrate for single particle analysis. Samples were stored in airtight containers at $4{ }^{\circ} \mathrm{C}$ and $20-30 \%$ RH. Table 1 lists the impactor samples analyzed and discussed in the context of this study.
The MOUDI stages were initially calibrated using flat $\mathrm{Al}$ foil (Marple et al., 1991). However, the relatively high thickness $(\sim 0.3 \mathrm{~mm})$ of the fiber filter and unequal sampling surface could modify the impaction characteristics. To estimate the retention efficiency of the filter in question, test experiments were conducted. Procedure and schematic diagrams of the test system are presented in Supplement S1. Figure 2a shows the collection characteristics of the MOUDI I and II stages that were used to sample the coarse mode $(\mathrm{CM} ;>1 \mu \mathrm{m})$ and accumulation mode (AM; $0.1-1 \mu \mathrm{m})$ of the aerosol size distribution. The results show that for stage II the collection efficiency reaches only $\sim 0.9$. Generally, fiber substrates combine impaction and filtration mechanisms and the resulting collection efficiency is higher than for a flat surface (Rao and Whitby, 1978). In our experiment only $13 \mathrm{~mm}$ filter disks were used for aerosol sampling, while the active impaction surface is $\sim 17 \mathrm{~mm}$. Therefore, some of the particles could have bounced off the surface of the Al substrate, as illustrated in Fig. S1.

Particle size distributions at the ZOTTO site were measured continuously with a DMPS/APS system (see Sect. 2.3.4). Figure $2 \mathrm{~b}$ shows the initial volume distributions (black symbols) of the atmospheric aerosol particles averaged during the sampling period and those that deposited on the impactor stages I and II. The volume distributions of the deposited particles were obtained by taking the product of the input initial distribution and the collection efficiency for every stage. The output distribution of stage I was obtained by subtracting the distributions of the particles deposited on this stage from the input particle distribution, which was consid- 

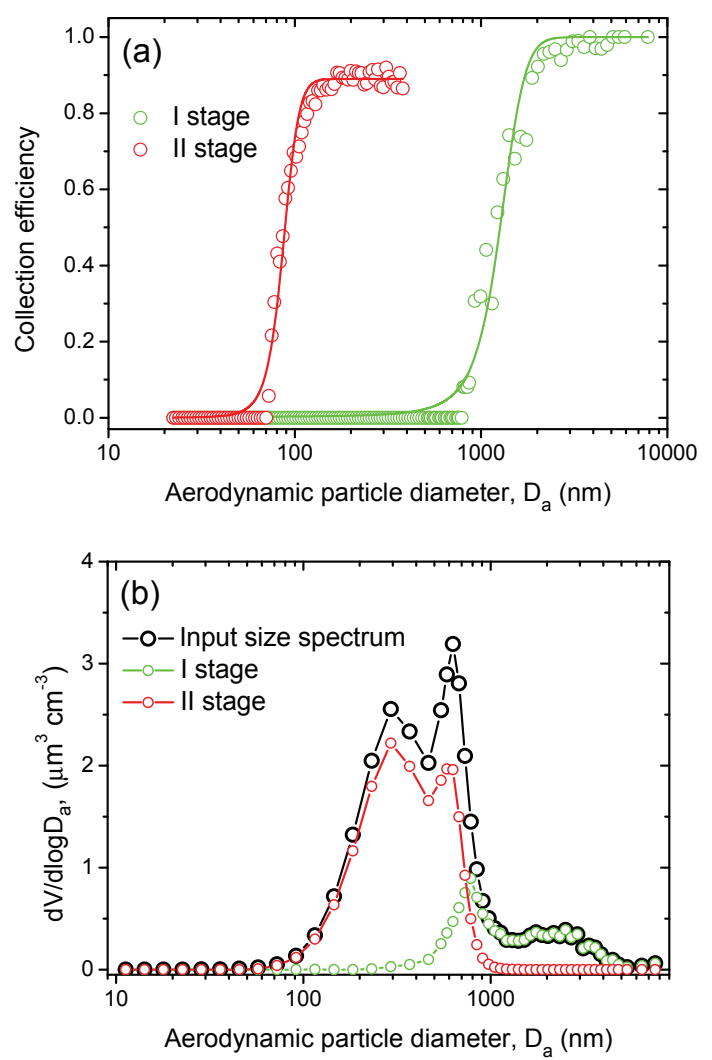

Figure 2. (a) Particle collection efficiency and (b) average volume distribution of the atmospheric aerosol particles deposited on the impactor stages of the MOUDI impactor. The collection efficiency data were fitted using a Boltzmann sigmoidal algorithm (solid lines).

ered as the input distribution for stage II. The obtained collection efficiency data were fitted by the Boltzmann sigmoidal function (Origin 8.0 software). The distributions obtained indicate that the aerosol loading on stage I represents the CM, whereas stage II represents the AM.

\subsection{Instrumentation}

\subsubsection{Organic carbon and elemental carbon analysis}

Organic carbon (OC), elemental carbon (EC), and total carbon $(\mathrm{TC}=\mathrm{OC}+\mathrm{EC})$ were measured by a thermal-optical transmission (TOT) technique (Birch and Cary, 1996), using a thermal-optical carbon analyzer from Sunset Laboratory (OR, USA). The temperature protocol used was the NIOSH5040 with a preset maximum of $870^{\circ} \mathrm{C}$ (Birch, 1998). The uncertainty in the OC, EC, and TC measurement is provided for every individual filter sample by the calculation program. The uncertainty is made up of a constant part (which is $0.2 \mu \mathrm{g} \mathrm{Cm}^{-2}$ for $\mathrm{OC}$ and $\mathrm{EC}$ and $0.3 \mu \mathrm{g} \mathrm{C} \mathrm{cm}^{-2}$ for TC) and of a variable part that amounts to $5 \%$ of the OC, EC, or TC mass loading. To correct for the positive artifact in the OC determination, two quartz filters in series were used (Maenhaut and Claeys, 2007). Both filters were pre-baked at $850^{\circ} \mathrm{C}$. The carbon loading on the second filter was subtracted from that on the first filter. Water-soluble organic carbon (WSOC) was determined by soaking part of the filter in water $(18.2 \mathrm{M} \Omega \mathrm{cm}$, Direct-Q3 UV, Millipore) for $12 \mathrm{~h}$, and after drying the remaining carbon in the filter was measured using the Sunset instrument.

\subsubsection{Ion chromatography analysis}

The aerosol-loaded filters were placed in $15 \mathrm{~mL}$ polystyrene tubes; $4 \mathrm{~mL}$ Millipore Simplicity water (TOC $<5 \mathrm{ppb}$; specific resistance $>18.2 \mathrm{M} \Omega \mathrm{cm}$ ) was added and the tubes were then placed typically in an ultrasonic ice-water bath for $30 \mathrm{~min}$, after which they were allowed to stand for $30 \mathrm{~min}$. The sample extract was then filtered through a PVDF syringe filter (pore size $0.2 \mu \mathrm{m}$ ) and the filtrate was subjected to IC analysis. A Dionex DX-500 instrument with an AG-22 guard, an AS-22 analytical column, and an ASRS-300 selfregenerating suppressor was used for the analysis of major inorganic anions $\left(\mathrm{Cl}^{-}, \mathrm{Br}^{-}, \mathrm{NO}_{2}^{-}, \mathrm{NO}_{3}^{-}, \mathrm{PO}_{4}^{3-}\right.$, and $\left.\mathrm{SO}_{4}^{2-}\right)$; the same instrument with a CG-12 A guard, a CS-12 A analytical column, and a CSRS self-regenerating suppressor was used for the measurement of major cations $\left(\mathrm{Na}^{+}, \mathrm{NH}_{4}^{+}, \mathrm{K}^{+}\right.$, $\mathrm{Mg}^{2+}$, and $\mathrm{Ca}^{2+}$ ). All columns had a $4 \mathrm{~mm}$ inner diameter. The anion analysis was done with a buffer eluent solution of $4.5 \mathrm{mM} \mathrm{Na}_{2} \mathrm{CO}_{3}$ and $1.4 \mathrm{mM} \mathrm{NaHCO}_{3}\left(0.5 \mathrm{~mL} \mathrm{~min}^{-1}\right)$ and a duration of $21 \mathrm{~min}$; the cation analysis was performed using a standard Dionex method, with $20 \mathrm{mM}$ methanesulfonic acid (isocratic) as eluent $\left(1.3 \mathrm{~mL} \mathrm{~min}^{-1}\right)$ and a duration of $12 \mathrm{~min}$. All IC analyses were made with manual injections; the injection loop for the anion analysis is $200 \mu \mathrm{L}$, while it is $25 \mu \mathrm{L}$ for the cation analysis. The ion analysis was conducted on the same MOUDI samples that were previously used for the hygroscopic growth experiment. The blank value was subtracted from the measured concentrations at each impactor stage. The total instrumental uncertainty of ion analysis (1 standard deviation) was approximately $10 \%$ for anions and cations (Leiva et al., 2012).

\subsubsection{X-ray micro-spectroscopy - STXM-NEXAFS and TEM}

$\mathrm{X}$-ray micro-spectroscopy was used to analyze aerosol samples on a single-particle basis. We applied scanning transmission $\mathrm{x}$-ray microscopy with near-edge $\mathrm{x}$-ray absorption fine structure analysis (STXM-NEXAFS) to determine the microstructure and chemical composition of aerosol particles with a volume equivalent diameter in the range of $0.3-3 \mu \mathrm{m}$ (Pöhlker et al., 2012). The STXM-NEXAFS analysis was conducted using two x-ray microscopes: (I) the MAXYMUS microscope at beamline UE46-PGM-2 (energy range 270$1900 \mathrm{eV})$ at synchrotron BESSY II $(1.7 \mathrm{GeV}, 100 \mathrm{~mA}$ stored current in low alpha decay mode), Helmholtz Center Berlin, 
Germany, and (II) the x-ray microscope at beamline 5.3.2.2 (energy range $250-800 \mathrm{eV}$ ) at the Advanced Light Source (1.9 GeV, $500 \mathrm{~mA}$ stored current in top-off mode), Berkeley, CA, USA. Both STXM instruments are equipped with a high energy resolving grating (resolving power at the carbon Kedge: ALS $\mathrm{E} / \Delta \mathrm{E} \leq 5000$; BESSY II: $\mathrm{E} / \Delta \mathrm{E} \leq 8000$ ), a Fresnel zone plate, providing a spatial resolution of about $30 \mathrm{~nm}$, and a phosphorous-coated Lucite photomultiplier tube for detection of transmitted photons. Further information about the x-ray microscopes can be found elsewhere (Follath et al., 2010; Kilcoyne et al., 2003).

$\mathrm{X}$-ray microscopy was performed by raster-scanning the aerosol samples in the focused $\mathrm{x}$-ray beam and measuring the intensity of the transmitted monochromatic light. Spectroscopic information is obtained by scanning the energy of the incident photons across the $\mathrm{x}$-ray absorption edges of several elements of interest (i.e., C, N, O, K, Ca, Fe, Al, and Na). A detailed description of STXM-NEXAFS analysis in aerosol science can be found in Moffet et al. (2010). The obtained STXM data were pre-processed using the aXis 2000 software (analysis of x-ray microscopy images and spectra), whereas final analysis was conducted using IGOR Pro (Wavemetrics) routines. Four aspects of the STXM analysis are presented in this study: (i) $x$-ray microscopy images at defined energies, (ii) elemental maps providing information about the spatial distribution of certain elements of interest, (iii) elemental ratios in individual aerosol particles based on x-ray absorption spectra covering the absorption edges of multiple elements, such as carbon $(\mathrm{C})$, nitrogen $(\mathrm{N})$, and oxygen $(\mathrm{O})$, and (iv) NEXAFS spectra characterizing the chemical environment of the elements $\mathrm{C}, \mathrm{N}$, and $\mathrm{O}$. A detailed description of the analysis can be found in Pöhlker et al. (2012).

The x-ray study of the particle morphology was supplemented by transmission electron microscopy (TEM) analysis. The samples were collected on $3 \mathrm{~mm}$ carbon-coated TEM grids, which were fixed in the center of $47 \mathrm{~mm}$ aluminum substrates and placed in the same MOUDI impactor stages as the Teflon-coated fiber glass filters. The sampling conditions for both STXM and TEM samples are listed in Table 1. TEM images were obtained with a LVEM5 (Delong) benchtop electron microscope, providing enhanced contrast on organic particles due to the low $(5 \mathrm{kV})$ acceleration voltage.

\subsubsection{Size distribution measurements}

Particle size distributions at ZOTTO are measured with a Differential Mobility Particle Sizer (DMPS) $(15-835 \mathrm{~nm})$ and an Aerodynamic Particle Sizer (APS 3321, TSI. Inc.) (0.5$20 \mu \mathrm{m})$. Detailed information about the ZOTTO DMPS system is given in Heintzenberg et al. (2011). The fitting of the DMPS to the APS was done in the following way. First the DMPS mobility diameter was converted to the aerodynamic diameter using a size-correction factor with an average weighted density for the accumulation mode of $1.54 \mathrm{~g} \mathrm{~cm}^{-3}$ (Table 5) and a shape factor of 1 (Khlystov et al., 2004).
Then the DMPS and APS size distributions were merged at the intersection range of $0.62-0.67 \mu \mathrm{m}$. The total overlap range was $583-835 \mathrm{~nm}$ and both APS and DMPS data points were in good agreement, indicating a second mode peak at $\sim 0.6 \mu \mathrm{m}$ (Fig. 2 b). For consistency with the chemical analysis and hygroscopic measurements that were conducted on the collected particles, no size correction for transmission losses in the inlet pipe line was made.

\subsubsection{Water uptake measurements}

Mass-based water uptake measurements were performed with a filter-based differential hygroscopicity analyzer (FDHA) using the atmospheric aerosol filter samples collected as described above (Sect. 2.2). The $13 \mathrm{~mm}$ filters loaded with the MOUDI impactor were mounted in the FDHA system. The particulate matter (PM) mass concentrations deposited on the filters in stages I and II are listed in Table 2. Details of the experimental setup and calibration are described elsewhere (Mikhailov et al., 2011, 2013). The measurement uncertainties depend on the weighing accuracy of dry particle mass (aerosol loading), the absorbed water mass (aerosol hygroscopicity), and the water vapor measurement precision of the katharometer (Mikhailov et al., 2011). In this study, the uncertainties in the determination of mass growth factors, $G_{\mathrm{m}}$ (Eq. 2), were $\sim 2 \%$ at $30 \% \mathrm{RH}$ and $\sim 10 \%$ at $99 \% \mathrm{RH}$. The relative humidity of the FDHA water uptake measurement is determined from the temperature ratio between the water vapor saturator and the measurement cells. The accuracy at $99 \% \mathrm{RH}$ was $\pm 0.06 \% \mathrm{RH}$, resulting from accurate temperature control using a double-wall copper housing with forced thermal insulation and precise temperature measurements $( \pm 0.01 \mathrm{~K}, 42095$-Pt100; KELVIMAT 4306, Burster).

The water uptake experiments were performed in two modes: hydration is increasing $\mathrm{RH}$; dehydration is decreasing RH. In both operational modes the RH was changed stepwise at a rate of $\sim 0.4 \% \mathrm{~min}^{-1}$. The potential particle mass lost due to evaporation was monitored by weighing the loaded filters before and after water uptake measurements. These measurements as well as subsequent hygroscopic data obtained in repetitive drying/humidifying cycles showed that the effect of particle evaporation was negligibly small. The experimental conditions in the measurement cells were close to ambient temperature and pressure $(\sim 295 \mathrm{~K}, \sim 1000 \mathrm{hPa})$.

\section{Water uptake modeling and parameterization}

The $\kappa$-mass interaction model (KIM) was used to describe and parameterize different regimes of hygroscopicity observed in our FDHA measurements. Details of the KIM are given elsewhere (Mikhailov et al., 2013). Briefly, in analogy with the volume-based hygroscopicity parameter (Petters et al., 2007), we define a mass-based hygroscopicity parameter, 
$\kappa_{\mathrm{m}}:$

$\frac{1}{a_{\mathrm{w}}}=1+\kappa_{\mathrm{m}} \frac{m_{\mathrm{d}}}{m_{\mathrm{w}}}$,

where $a_{\mathrm{w}}$ is the activity of water, $m_{\mathrm{d}}$ is the total mass of the dry particle material, and $m_{\mathrm{w}}$ is the mass of water in the wet particle (aqueous droplet). By defining the mass growth factor, $G_{\mathrm{m}}$, as

$G_{\mathrm{m}}=\frac{m_{\mathrm{w}}+m_{\mathrm{d}}}{m_{\mathrm{d}}}$

and combining Eq. (1) and Eq. (2), we obtain

$a_{\mathrm{w}}=\left(\frac{\kappa_{\mathrm{m}}}{G_{\mathrm{m}}-1}+1\right)^{-1}$.

Based on Eq. (3), an approximate mass-based $\kappa_{\mathrm{m}}-$ Köhler equation can be written as follows:

$$
\frac{\mathrm{RH}}{100 \%}=s_{\mathrm{w}} \approx\left(\frac{\kappa_{\mathrm{m}}}{G_{\mathrm{m}}-1}+1\right)^{-1} \exp \left(\frac{4 \sigma_{\mathrm{w}} M_{\mathrm{w}}}{R T \rho_{\mathrm{w}} D_{\mathrm{d}}}\left[\frac{\rho_{\mathrm{w}}}{\rho_{\mathrm{d}} G_{\mathrm{m}}}\right]^{1 / 3}\right)
$$

where $M_{\mathrm{w}}, \sigma_{\mathrm{w}}$, and $\rho_{\mathrm{w}}$ are the molar mass, surface tension, and density of pure water, $R$ is the universal gas constant, $T$ is the temperature, and $D_{\mathrm{d}}$ and $\rho_{\mathrm{d}}$ are the volume equivalent diameter and density of the dry particle. The concentration dependence of $\kappa_{\mathrm{m}}$ in the KIM is expressed as follows:

$\kappa_{\mathrm{m}}=\sum_{i} \kappa_{\mathrm{m}, i}^{0} c_{\mathrm{m}, i}+\sum_{i<} \sum_{j} \alpha_{i j} c_{\mathrm{m}, i} c_{\mathrm{m}, j}+\sum_{i} \alpha_{i i} c_{\mathrm{m}, i}^{2}$.

Here $\kappa_{\mathrm{m}, i}^{0}$ is the dilute hygroscopicity, $\alpha_{i j}$ and $\alpha_{i i}$ are the cross- and self-interaction coefficients, respectively, and $c_{\mathrm{m}, i}$ and $c_{\mathrm{m}, j}$ are the mass concentrations of individual components $(i, j)$ in the aqueous solution. The mass concentration of each component in the aqueous solution, $c_{\mathrm{m}, i}$, can be calculated either from the solubility (if component $i$ is only partially dissolved) or from the dry mass fraction (if component $i$ is fully dissolved). For mixed organic-inorganic particles, KIM describes three distinctly different regimes of hygroscopicity: (I) a quasi-eutonic deliquescence and efflorescence regime at low humidity, where substances are just partly dissolved and exist also in a non-dissolved phase; (II) a gradual deliquescence and efflorescence regime at intermediate humidity, where different solutes undergo gradual dissolution or solidification in the aqueous phase; and (III) a dilute regime at high humidity, where the solutes are fully dissolved, approaching their dilute hygroscopicity. In each of these regimes, the concentration dependence of $\kappa_{\mathrm{m}}$ can be described by simplified model equations:

Regime I:

$\kappa_{\mathrm{m}}=k_{1}\left(G_{\mathrm{m}}-1\right)$

Regime II:

$\kappa_{\mathrm{m}}=k_{2}+k_{3}\left(G_{\mathrm{m}}-1\right)+k_{4}\left(G_{\mathrm{m}}-1\right)^{-1}+k_{5}\left(G_{\mathrm{m}}-1\right)^{-2}$
Regime III:

$\kappa_{\mathrm{m}}=k_{5}\left(G_{\mathrm{m}}-1\right)^{-2}+k_{6}$.

Here $k_{1}$ to $k_{6}$ are fit parameters related to the solubility and interaction coefficients of all involved chemical components (Mikhailov et al., 2013; Eqs. 39-44). In Eq. (8) the fit parameter $k_{6}=\kappa_{\mathrm{m}}^{0}$ can be regarded as the dilute hygroscopicity parameter of the investigated sample of particulate matter (Fig. 3b). Its physical meaning is equivalent to the volumebased parameter, $\kappa_{\mathrm{v}}$, proposed by Petters and Kreidenweis (2007).

Figure 3a shows an illustrative example of KIM assuming a two-component mixture (A and $\mathrm{B}$ ) having deliquescence relative humidities $\mathrm{DRH}_{\mathrm{A}}$ and $\mathrm{DRH}_{\mathrm{B}}$, respectively (Wexler and Seinfeld, 1991). At $\mathrm{RH}_{\mathrm{eu}}$ mixed particles partially deliquesce (I, green line) and the concentration of each component is given by the eutonic (eu) solubility, $C_{\mathrm{eu}}$; as the $\mathrm{RH}$ increases further, gradual dissolution of the solid component A occurs (mode II, yellow area). At the relative humidity of $\mathrm{RH}_{\mathrm{fd}}$ both components are fully dissolved (fd) with a composition equal to the initial particle composition, $C_{\mathrm{A}, \mathrm{B}}$. The subsequent increase in $\mathrm{RH}$ leads to dilution of the aqueous solution (III, blue area). This simplified two-component diagram can be extended to a multicomponent mixture. Figure $3 b$ illustrates the respective changes of the $\kappa_{\mathrm{m}}$, which are captured by Eqs. (6)-(8). Note that these equations can also be used to describe and parameterize mixed particles that are in a metastable state (Fig. 3b, red dashed line). Specifically, in KIM the "quasi-eutonic deliquescence and efflorescence" states are considered to characterize partly dissolved solutes that may co-exist in metastable equilibrium with amorphous phases (Mikhailov et al., 2013) that undergo quasi-eutonic deliquescence $\left(\mathrm{RH}_{\mathrm{eu}}\right)$ and quasi-eutonic efflorescence $\left(\mathrm{RH}_{\mathrm{ef}}\right)$, respectively (Fig. 3b).

\section{Results and discussion}

\subsection{Chemical composition}

The aerosol chemical mass closure calculations were made in a similar way as done by Maenhaut et al. (2002). The reconstructed PM mass for accumulation and coarse mode was obtained as the sum of eight aerosol species, which were calculated as follows: (1) ammonium $\left(\mathrm{NH}_{4}^{+}\right)$; (2) nitrate $\left(\mathrm{NO}_{3}^{-}\right)$; (3) sea salt estimated as $1.4486\left[\mathrm{Na}^{+}\right]+\left[\mathrm{Cl}^{-}\right]$, where 1.4486 is the ratio of the concentration of all elements except $\mathrm{Cl}^{-}$in sea water to the $\mathrm{Na}^{+}$concentration; (4) nonsea-salt (nss) sulfate is obtained as total sulfate minus sea-salt sulfate, whereby the latter was obtained as $0.252\left[\mathrm{Na}^{+}\right]$, with 0.252 the mass ratio of $\mathrm{SO}_{4}^{2-}$ to $\mathrm{Na}^{+}$in seawater (Riley and Chester, 1971); (5) nss- $\mathrm{K}^{+}-$as total $\mathrm{K}^{+}-0.0376\left[\mathrm{Na}^{+}\right]$; (6) nss-Ca ${ }^{2+}-$ as total $\mathrm{Ca}^{2+}-0.0382\left[\mathrm{Na}^{+}\right]$; (7) elemental carbon (EC); and (8) organic matter (OM) as estimated as PM $\left(\mathrm{EC}+\sum\right.$ inorganic_species $)$. The measured OC data could 
Table 2. Reconstructed particulate matter (PM) concentrations in the accumulation $(0.1-1 \mu \mathrm{m})$ and coarse $(>1 \mu \mathrm{m})$ size modes. The uncertainty ( 1 standard deviation) of the ion analysis is $\sim 10 \%$ for anions and cations. For carbonaceous material the uncertainties arise from standard instrumental error of the SunSet instrument and the assumptions used, and are estimated overall to be $\sim 30 \%$.

\begin{tabular}{llrrrrrrrrrr}
\hline Aerosol size & $\mathrm{PM}$ & \multicolumn{10}{c}{ Chemical species concentration $\left(\mathrm{ng} \mathrm{m}^{-3}\right)$} \\
\cline { 3 - 12 } mode $(\mu \mathrm{m})$ & $\left(\mathrm{ng} \mathrm{m}^{-3}\right)$ & Sea salt & $\mathrm{Nss}^{-S^{2-}}$ & $\mathrm{NH}_{4}^{+}$ & $\mathrm{Nss}_{4} \mathrm{~K}^{+}$ & $\mathrm{Nss}_{-} \mathrm{Ca}^{2+}$ & $\mathrm{NO}_{3}^{-}$ & $\mathrm{EC}$ & $\mathrm{OM}$ & WSOM & WIOM \\
\hline $0.1-1$ & $1600 \pm 20$ & 7.7 & 438 & 137 & 20.7 & 1.2 & 0.4 & 17.0 & 976 & 830 & 146 \\
$>1$ & $510 \pm 20$ & 33.7 & 205 & 57.8 & 9.7 & 7.1 & n.a. & 3.3 & 196 & 41.2 & 155 \\
\hline
\end{tabular}
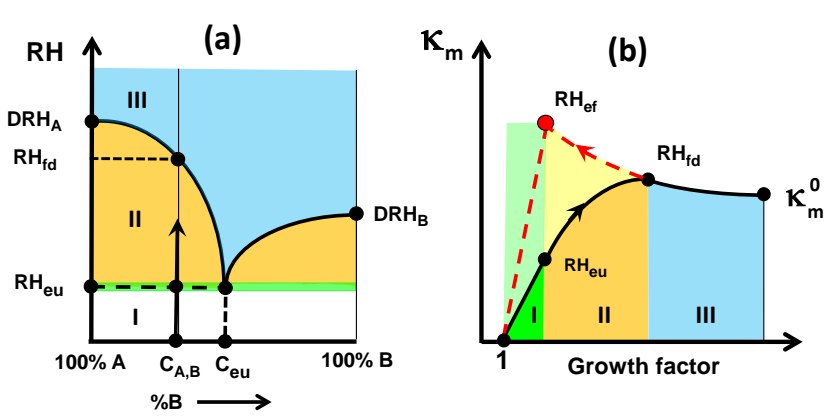

Figure 3. An illustrative example of KIM assuming a twocomponent mixture (A, B): (a) - phase diagram; (b) - the respective variation of the hygroscopicity, $\kappa_{\mathrm{m}}$, due to water uptake. The light colored areas are responsible for the metastable state of the solution. Explanation and designations are given in the text.

not be used for this purpose, since the OC measurement was done on total PM filters, without size fractionation.

Mineral dust was not considered in the mass closure since the STXM-NEXAFS results indicate the absence of significant dust-like components in the samples (Fig. S2.2). In STXM analysis, mineral dust particles are typically a rather noticeable phenomenon due to their comparably large size, irregularly shaped morphology, and strong absorption (i.e., at carbon pre-edge and also at the oxygen edge due to $\mathrm{Al}, \mathrm{Si}$, and Fe oxides). Most of the observed particles differ strongly from dust-like particles in morphology and absorption properties.

Elemental carbon and organic carbon were measured for total PM; therefore, several simplifying assumptions were used to estimate EC, water-soluble (WSOM), and water-insoluble (WIOM) organic matter in the coarse- and accumulation-mode fractions of the ZOTTO samples. First, EC was divided between AM and CM as 5:1, which is a typical ratio for smoke particles (Jaffrezo et al., 2005; SotoGarcía et al., 2011; Liu et al., 2013). Second, we assume that the WSOM / OM ratio is equal to 0.85 for AM and 0.21 for CM. Details of the calculation are presented in Supplement S3. Reconstructed contents of the inorganic and organic species for $\mathrm{AM}$ and $\mathrm{CM}$ are reported in Table 2 and shown in Fig. 4. In both size fractions, $\mathrm{SO}_{4}^{2-}$ and $\mathrm{NH}_{4}^{+}$ are the dominant ions, with sulfate ions accounting for 27 and $40 \%$ of particulate matter in $\mathrm{AM}$ and $\mathrm{CM}$, respectively
(Fig. 4). Some of the sulfates could have come from forest fires located to the east of the ZOTTO site, but these must be a minor source, because the typical sulfate content in aged biomass smoke is only about $5 \%$. Additionally, sulfates could also have natural sources, namely, the oxidation of marine-emitted dimethylsulfide (Levasseur, 2013). Again, this can only account for a minor fraction because biogenic sulfate aerosol concentrations in the Arctic are typically less than $100 \mathrm{ng} \mathrm{m}^{-3}$ even in summer, when this source is strongest ( $\mathrm{Li}$ and Barrie, 1993; Norman et al., 1999; Quinn et al., 2002; Ström et al., 2003; Gong et al., 2010; Chang et al., 2011). Most of the sulfate must thus be of anthropogenic origin, arriving from the north with the Arctic airflow, which passed at $\sim 400 \mathrm{~km}$ by Norilsk (Fig. 1), a powerful source of $\mathrm{SO}_{2}$ (Walter et al., 2002). This is consistent with the backtrajectory analysis (Fig. 1) and CO levels (Table 1), which indicate a significant influence of Arctic and eastern air masses at the ZOTTO site.

Sea salt is the next important inorganic component in $\mathrm{CM}(6.6 \%)$, suggesting a predominant origin by long-range transport from the Arctic Ocean (Fig. 1). Nss- $\mathrm{K}^{+}$was the second-most abundant cation and accounted for 1.3 and $1.9 \%$ of PM in the accumulation and coarse modes. Generally, $\mathrm{K}^{+}$is a good indicator of biomass burning and could have come with eastern air masses from the biomass burning area (Fig. 1). However, given the lack of intense forest fires (EC/TC $\sim 2 \%$ ), the primary emission of $\mathrm{nss}^{-} \mathrm{K}^{+}$from biogenic sources should not be neglected. Active biota such as plants and fungi are known to be an additional source of atmospheric K-rich salts in the air (Pöhlker et al., 2012). A small amount of nss-Ca ${ }^{2+}$ was observed in both accumulation $(<0.1 \%)$ and coarse $(1.4 \%)$ mode. Coarse ash particles emitted from wood combustion generally contain significant amounts of $\mathrm{Ca}$ along with $\mathrm{Mg}, \mathrm{Si}, \mathrm{Al}, \mathrm{Fe}$, and $\mathrm{K}$ (Pitman, 2006). Enriched $\mathrm{Ca}^{2+}$ may be also produced by processes within clouds, which bring sea salt and mineral particles together, or by the reaction of atmospheric $\mathrm{SO}_{2}$ with marine biogenic $\mathrm{CaCO}_{3}$ particles (coccoliths) (Andreae et al., 1986). More likely, the latter process dominated since no mineral particles were identified in the CM by NEXAFS analysis. Overall, as expected, the water-soluble fraction of all inorganic ions prevails in $\mathrm{CM}$ particles, with a mean fraction $61 \%$ vs. $38 \%$ for AM. 


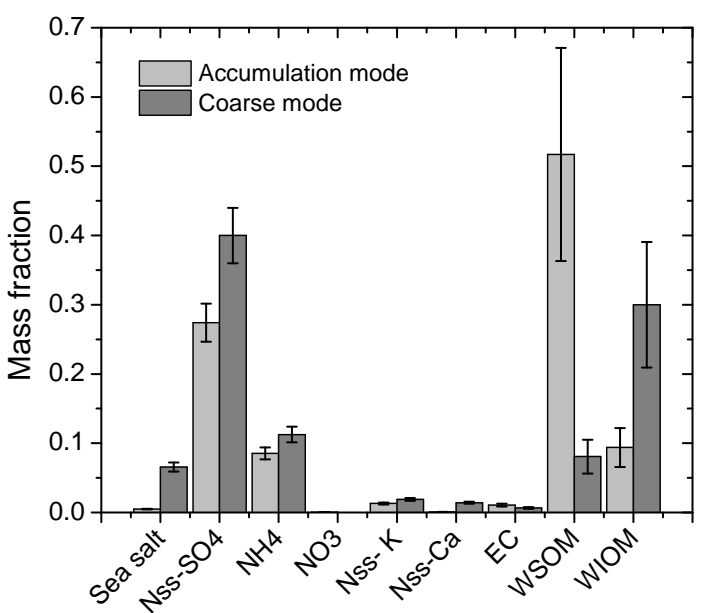

Figure 4. Average mass fraction of organic and inorganic species in the accumulation and coarse modes of the ZOTTO samples.

Organic compounds account for a large fraction of air particulate mass (Table 2): OM / PM ratios in AM and CM are as high as 61 and $38 \%$, and the WSOM fraction was estimated to be $\sim 52 \%$ in $\mathrm{AM}$ and $\sim 8 \%$ in $\mathrm{CM}$, respectively (Fig. 4). The measured concentrations of $\mathrm{OC}$ and $\mathrm{EC}$ in total PM were $1000 \pm 60 \mathrm{ng} \mathrm{m}^{-3}$ and $20.3 \pm 5.6 \mathrm{ng} \mathrm{m}^{-3}$, respectively, in reasonable agreement with the sum of the reconstructed $\mathrm{OM}$ values $\left(1170 \mathrm{ng} \mathrm{m}^{-3}\right)$. These concentrations are a factor of 2.4 lower for $\mathrm{OC}$ and a factor of 8 lower for EC than those measured by Maenhaut et al. (2011) in the summer season at the SMEAR II background boreal station (Hyytiälä, Finland). The low content of elemental carbon (EC / OC 2\%) suggests that during our field campaign the effect of forest fires and fossil fuel combustion on the carbonaceous aerosol fraction was modest. The most likely sources of the particulate organic carbon are atmospheric oxidation processes, which convert biogenic volatile organic compounds (BVOCs), such as monoterpenes and sesquiterpenes emitted by the boreal ecosystem, to secondary organic aerosol (Kanakidou et al., 2005; Corrigan et al., 2013; Chi et al., 2013; Mikhailov et al., 2015).

The WSOC / OC ratio was estimated at $0.67 \pm 0.06$. Such a high water-soluble fraction suggests that the atmospheric conditions in summer may favor the further oxidation of the secondary organic compounds towards higher water solubility. Our results are comparable with earlier data reported for forest environments in the summer season: WSOC / OC = $0.70 \pm 0.09$ (Timonen et al., 2008) and $0.71 \pm 0.05$ (Kiss et al., 2002).

The high level of WIOM $(\sim 30 \%)$ in CM can be explained by the presence of primary biogenic particles, e.g., plant debris, spores, bacteria and pollen (Pöschl et al., 2010). Internally mixed particles of sea salt and organic matter also can be produced via aerosol-cloud processing and fragmentation of organic-rich surface film layers during the bursting of air bubbles at the sea surface (Andreae and Rosenfeld, 2008). In general, the mass closure analysis is in agreement with the results of single-particle elemental composition as observed by STXM-NEXAFS, which also showed a dominant abundance of organic particulate matter and ammoniated sulfates (see next section).

\subsection{Aerosol microstructure - STXM-NEXAFS and TEM analysis}

Limited particle statistics is an inherent difficulty of most single particle techniques. Thus, we applied two different single particle approaches in this study to broaden the statistical basis and to check the consistency of the independent data sets. The total particle number that has been probed with STXM is 150 , while the total particle number for TEM analysis is 810 . The TEM data allow a classification of the particle ensemble based on morphology, while the STXM data (though more limited in statistics) provide more detailed insights into the chemical composition and therefore complement the TEM data set. The visual TEM analysis of $725 \mathrm{AM}$ and $85 \mathrm{CM}$ aerosol particles has revealed three main morphology types: (i) homogeneous spheres, which can be attributed to terpeneand isoprene-based SOA droplets (Kourtchev et al., 2005; Pöschl et al., 2010), (ii) mixed SOA-inorganic particles with core-shell morphology, and (iii) irregularly shaped primary biological aerosol (PBA) particles, such as plant fragments. In the submicron particle range the balance between uncoated (type i) and coated (type ii) aerosol particles is 32 and $62 \%$, respectively, which agrees with the STXM data. Approximately $5 \%$ can be attributed to PBA particles with an organic coating fraction of $\sim 50 \%$. In the coarse particle mode almost all aerosol particles are internally mixed with surface organic coating $(\sim 80 \%)$. Among them $\sim 20 \%$ have a high-contrast-density outer core (Fig. 7d-f) presumably formed from sparingly soluble organic species due to liquidliquid phase separation upon particle dehydration (Song et al., 2012). Approximately $13 \%$ are PBA particles. In addition, a minor fraction $(<1 \%)$ of the fractal-like soot aggregates was found on the TEM images of the AM and CM aerosol particles.

The $\mathrm{x}$-ray analysis showed that the size range of the particles collected on the sampling substrates $\left(\mathrm{Si}_{3} \mathrm{~N}_{4}\right.$ membranes) is consistent with the aerosol size distribution in Fig. 2b. The majority of particles is present in the AM size range (0.3$1 \mu \mathrm{m})$, with a small number of larger CM particles $(>1 \mu \mathrm{m})$ (Fig. S2.1).

To characterize the overall elemental abundance in the collected particles, multiple STXM maps of relatively large areas have been recorded from all samples and confirm the bulk chemical analysis, showing that $\mathrm{SO}_{4}^{2-}, \mathrm{NH}_{4}^{+}$, and $\mathrm{OM}$ are the predominant constituents of the aerosol (example shown in Fig. S2.2). X-ray spectroscopic evidence for the dominance of $\mathrm{SO}_{4}^{2-}, \mathrm{NH}_{4}^{+}$, and $\mathrm{OM}$ in the particles is shown in Fig. S2.3. Based on the x-ray absorp- 

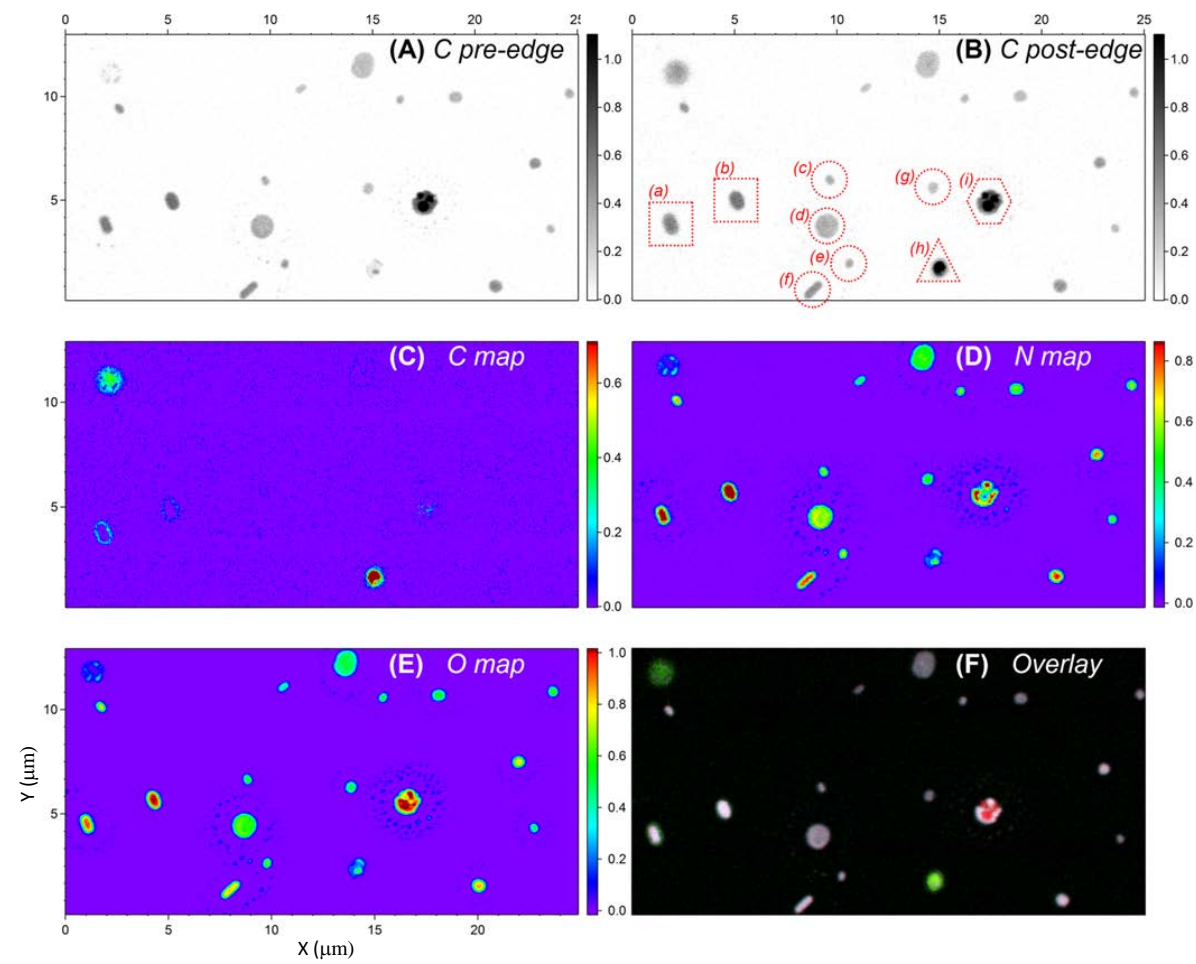

Figure 5. STXM images and elemental maps of representative accumulation mode particles in the ZOTTO aerosol samples. The particles shown here represent a volume equivalent diameter range of $0.3-0.6 \mu \mathrm{m}$. (Panels a and b): carbon pre- and post-edge images; panel (c): carbon elemental map; panel (d): nitrogen map; panel (e): oxygen map; and panel (f): overlay of C (green), $\mathrm{N}$ (blue), and O (red) maps. Axes in panels (a)-(e) display image dimensions in $\mu \mathrm{m}$. Optical density (color code) is displayed for individual maps. Red boxes and labels in panel (b) exemplify the most common particle types in STXM samples: (a) and (b) show internally mixed particles with ammoniated sulfate core and organic coating; (c)-(g) show mostly purely inorganic ammoniated sulfate particles; (i) shows ammoniated sulfate with potassium; and (h) shows a C-rich particle with small inorganic content.

tion spectra, the elemental ratio $\mathrm{N} / \mathrm{O}_{\text {sulfate }}=0.54 \pm 0.12$ was calculated (ion chromatography results in Fig. 4 gave $\mathrm{N} / \mathrm{O}_{\text {sulfate }}=0.41 \pm 0.16$ ). This suggests a sulfate salt composition close to ammonium sulfate $\left[\left(\mathrm{NH}_{4}\right)_{2} \mathrm{SO}_{4} ; \mathrm{N} / \mathrm{O}=\right.$ $0.5]$ and/or letovicite $\left[\left(\mathrm{NH}_{4}\right)_{3} \mathrm{H}\left(\mathrm{SO}_{4}\right)_{2} ; \mathrm{N} / \mathrm{O}=0.38\right]$. The individual particles comprise highly variable amounts of $\mathrm{OM}$ with $\mathrm{OM} /\left(\mathrm{NH}_{4}\right)_{2-x} \mathrm{H}_{x}\left(\mathrm{SO}_{4}\right)$ mass ratios in the range of 0 0.9 .

Elemental maps of typical particles are shown in Figs. 5 and 6. Figure 5 displays particles in the AM size range, which exhibit spherical or elliptical morphologies with variable OM contents and core-shell structure for a certain fraction of particles. In contrast, Fig. 6 shows comparably large particles (CM size range) with conspicuous internal structures and comparably high OM contents. The difference in OM content can also be seen in Fig. 6. All internally mixed $\left(\mathrm{NH}_{4}\right)_{2-x} \mathrm{H}_{x}\left(\mathrm{SO}_{4}\right) / \mathrm{OM}$ particles reveal a clear separation of the inorganic and organic phases.

Complementary to the STXM results, TEM images in Fig. 7 show particles with core-shell structures. The cores appear as dendritic crystalline-like material and resemble similar dendritic sulfate salt structures in the STXM image,
Fig. 6 (i.e., particles b, c, e, and f). Moreover, the TEM images also display OM shells of different thicknesses around the particles (Fig. 7).

\subsection{Hygroscopic properties and KIM results}

Figure 8a and c show the mass growth factors, determined as a function of relative humidity upon hydration and dehydration for accumulation and coarse size modes as detailed in Sect. 2.3.5. The different symbols represent repetitive measurements on the same sample, indicating a good reproducibility of the water uptake/release results and a negligibly small effect of particle evaporation due to semivolatile organics. The onset of deliquescence at $\sim 70 \% \mathrm{RH}$ is evident for the accumulation (Fig. 8a) and coarse (Fig. 8c) modes. Upon dehydration these size modes also exhibit an efflorescence transition at $37 \%$ RH (insert in Fig. 8a) and at $49 \%$ $\mathrm{RH}$, respectively. Figure 8c indicates a hysteresis for the $\mathrm{CM}$ mode starting at $\sim 95 \% \mathrm{RH}$, i.e., well before the particles deliquescence. The kinetics and morphology effects of the supermicron size particles might be responsible for this effect, as will be discussed below. 

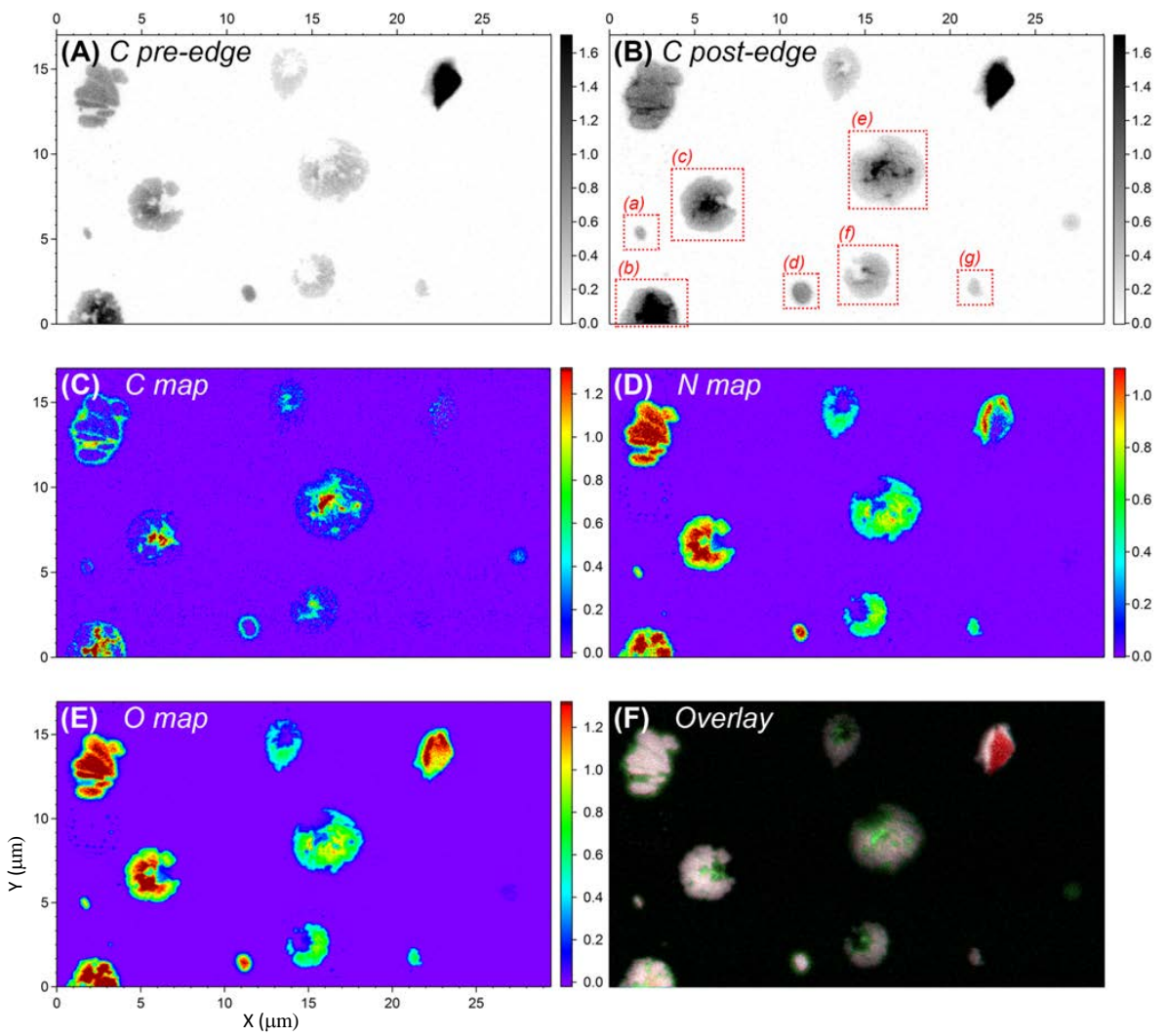

Figure 6. STXM images and elemental maps of representative particles in the coarse mode range with some smaller accumulation mode particles. The particles shown here represent a volume equivalent diameter range of 0.6-1.9 $\mu \mathrm{m}$. (a, b) Carbon pre- and post-edge images, (c) carbon elemental map, (d) nitrogen map, (e) oxygen map, and (f) overlay of C (green), N (blue), and O (red) maps. Axes in (a)-(e) display image dimensions in $\mu \mathrm{m}$. Optical density (color code) is displayed for individual maps. Red boxes and labels in (b) highlight internally mixed particles with ammoniated sulfate and variable amounts of organics.

From the measurement of the $G_{\mathrm{m}}(\mathrm{RH})$ data we derived mass-based hygroscopicity parameters using Eqs. (3) and (4) and the Kelvin correction algorithm for submicron particles as described by Mikhailov et al. (2013, Appendix C). The corresponding plots of $\kappa_{\mathrm{m}}$ vs. $G_{\mathrm{m}}$ are shown in Fig. $8 \mathrm{~b}$ and $\mathrm{d}$ for $\mathrm{AM}$ and $\mathrm{CM}$, respectively. In all size modes the observed dependence of $\kappa_{\mathrm{m}}$ on $G_{\mathrm{m}}$ exhibits three distinctly different sections or regimes of hygroscopicity as outlined in Sect. 3 and in Fig. 3. The model lines were obtained by inserting the fit parameters from Table 3 into Eqs. (6)-(8). For the quasi-eutonic regime (I), the combination of Eq. (3) and Eq. (6) yields a constant water activity value given by $a_{\mathrm{w}}=\left(k_{1}+1\right)^{-1}$. This relation yields the following quasieutonic RH values characterizing the deliquescence (Ia) and efflorescence (Ib) phase transitions: $74.6 \%$ (36.7\%) for AM, and $70.0 \%$ (49.8\%) for CM, respectively (Fig. 8b, d). The gradual deliquescence mode (II) extended up to $96 \%$ RH for the coarse mode and even further up to $97 \%$ for the accumulation mode, indicating the presence of sparingly soluble OC in both fractions. In the dilution regime (III) (Eq. 8), the fit parameter $k_{6}=\kappa_{\mathrm{m}}^{0}$ obtained for submicron aerosol particles is $0.061 \pm 0.002$ (Table 3). This value can be com- pared to the dilute hygroscopicity obtained for $\mathrm{PM}_{1}$ samples during the Amazonian Aerosol Characterization Experiment (AMAZE-08) in the wet season (Mikhailov et al., 2013), where $\kappa_{\mathrm{m}}^{0}=0.104 \pm 0.002$. The observed $\sim 40 \%$ discrepancy in $\kappa_{\mathrm{m}}^{0}$ between Amazon and Siberian samples may be caused by differences in their chemical composition. Hygroscopic ammoniated sulfate is a good candidate for the observed difference. However, for the AMAZE-08 campaign, the average sulfate loading measured by ion chromatography was only $0.21 \mathrm{\mu g} \mathrm{m}^{-3}$ (Chen et al., 2009). This concentration is less than half that determined in the Siberian sample $\left(0.44 \mu \mathrm{g} \mathrm{m}^{-3}\right.$, Table 2$)$. One possible explanation is that the ammoniated sulfate in the Siberian aerosol sample was partly isolated by sparingly soluble organic species and therefore was not completely involved in hygroscopic growth. This potential mass transfer limitation effect will be considered below.

Another possible reason for the increased hygroscopicity of the Amazon sample is that the biogenic SOA produced by tropical rainforests contains more hygroscopic species than that produced in the Siberian boreal zone. It was found that the formation of WSOC is closely linked to photosyn- 


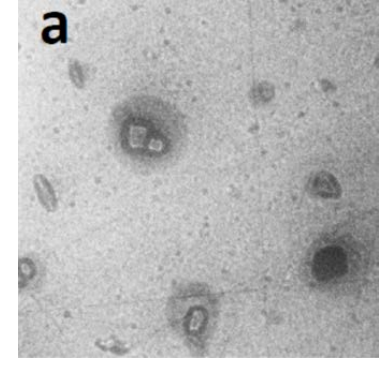

$1 \mu \mathrm{m}$

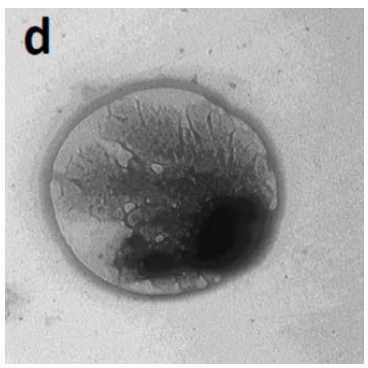

$1 \mu \mathrm{m}$

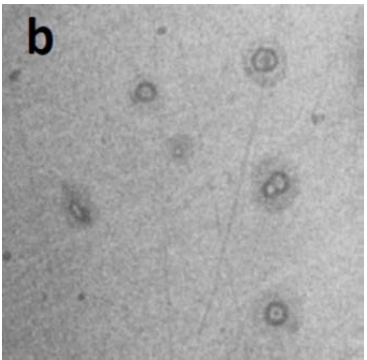

$1 \mu \mathrm{m}$

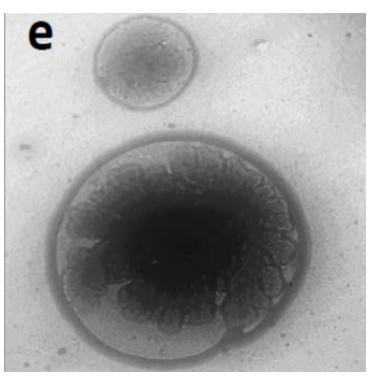

$1 \mu \mathrm{m}$

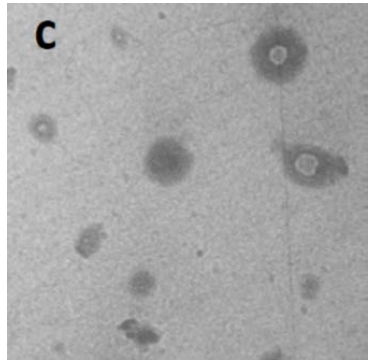

$1 \mu \mathrm{m}$

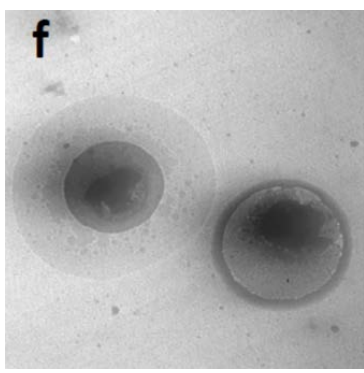

$1 \mu \mathrm{m}$

Figure 7. TEM micrographs of submicron $(\mathbf{a}, \mathbf{b}, \mathbf{c})$ and supermicron $(\mathbf{d}, \mathbf{e}, \mathbf{f})$ particles.
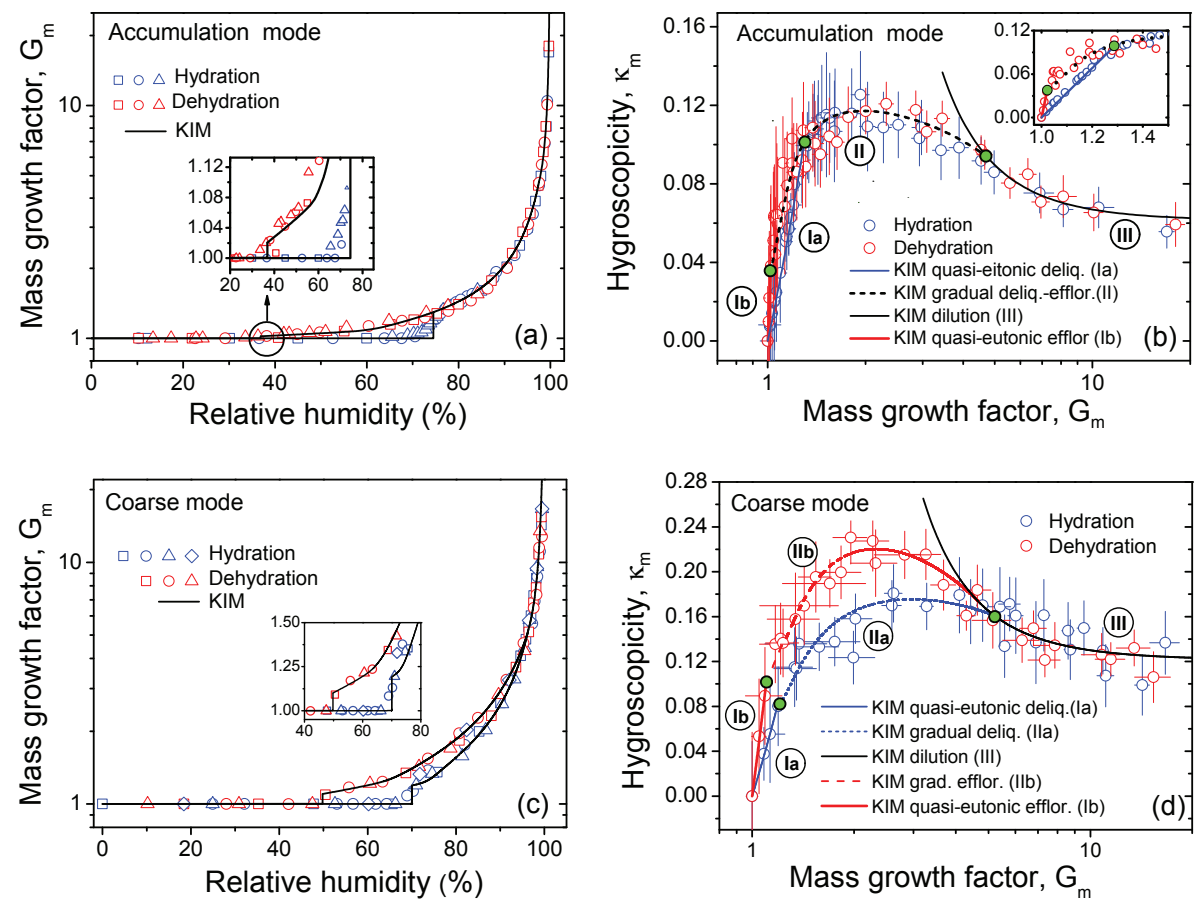

Figure 8. Hygroscopic properties of accumulation $(\mathbf{a}, \mathbf{b})$ and coarse $(\mathbf{c}, \mathbf{d})$ modes of ZOTTO aerosol samples: $(\mathbf{a}, \mathbf{c})$ mass growth factors $\left(G_{\mathrm{m}}\right)$ observed as a function of relative humidity compared to KIM; (b, d) mass-based hygroscopicity parameters $\left(\kappa_{\mathrm{m}}\right)$ calculated as a function of mass growth factor. The data points and error bars are from FDHA experiments of hydration (blue symbols) and dehydration (red symbols). The labels I (Ia, Ib), II (IIa, IIb) and III indicate different regimes of hygroscopicity (Eqs. 6-8); the borders of the corresponding fit intervals are indicated by green circles $(\mathbf{b}, \mathbf{d})$. Varied symbols in panels (a) and (c) represent different experimental runs on the same sample. 
Table 3. KIM fit parameters for the accumulation $(0.1-1 \mu \mathrm{m})$ and coarse $(>1 \mu \mathrm{m})$ aerosol size modes collected at ZOTTO (Siberia); $n$ and $R^{2}$ are the number of data points and the coefficient of determination of the fit.

\begin{tabular}{|c|c|c|c|c|c|c|}
\hline Size mode & Regime & $G_{\mathrm{m}}$ range & $n$ & $R^{2}$ & $\begin{array}{l}\text { Fit } \\
\text { equation }\end{array}$ & $\begin{array}{l}\text { Best fit parameter } \\
\pm \text { standard error }\end{array}$ \\
\hline \multirow[t]{4}{*}{ Accumulation } & $\begin{array}{l}\text { Quasi-eutonic deliques- } \\
\text { cence (Ia) }\end{array}$ & $1-1.3$ & 14 & 0.98 & 6 & $k_{1}=0.342 \pm 0.005$ \\
\hline & $\begin{array}{l}\text { Gradual deliquescence } \\
\text { and efflorescence (II) }\end{array}$ & $1.3-4.6$ & 32 & 0.86 & 7 & $\begin{array}{l}k_{2}=0.140 \pm 0.004 \\
k_{3}=-1.16 \times 10^{-2} \pm 8.7 \times 10^{-4} \\
k_{4}=-1.19 \times 10^{-2} \pm 1.5 \times 10^{-3} \\
k_{5}(\mathrm{II})=4.19 \times 10^{-4} \pm 8 \times 10^{-5}\end{array}$ \\
\hline & Dilution (III) & $4.6-9.1$ & 14 & 0.87 & 8 & $\begin{array}{l}k_{5}(\mathrm{III})=0.45 \pm 0.05 \\
k_{6}=0.061 \pm 0.002\end{array}$ \\
\hline & $\begin{array}{l}\text { Quasi-eutonic } \\
\text { efflorescence (Ib) }\end{array}$ & $1.02-1$ & 4 & 0.97 & 6 & $k_{1}=1.70 \pm 0.07$ \\
\hline \multirow[t]{5}{*}{ Coarse } & $\begin{array}{l}\text { Quasi-eutonic deliques- } \\
\text { cence (Ia) }\end{array}$ & $1-1.2$ & 4 & 0.99 & 6 & $k_{1}=0.43 \pm 0.01$ \\
\hline & $\begin{array}{l}\text { Gradual deliquescence } \\
\text { (IIa) }\end{array}$ & $1.2-5.2$ & 19 & 0.61 & 7 & $\begin{array}{l}k_{2}=0.23 \pm 0.02 \\
k_{3}=-0.012 \pm 0.003 \\
k_{4}=-0.05 \pm 0.02 \\
k_{5}(\mathrm{II})=0.005 \pm 0.003\end{array}$ \\
\hline & Dilution (III) & $5.2-16.6$ & 28 & 0.56 & 8 & $\begin{array}{l}k_{5}(\mathrm{III})=0.50 \pm 0.08 \\
k_{6}=0.128 \pm 0.004\end{array}$ \\
\hline & $\begin{array}{l}\text { Gradual efflorescence } \\
\text { (IIb) }\end{array}$ & $4.50-1.1$ & 14 & 0.84 & 8 & $\begin{array}{l}k_{2}=0.308 \pm 0.006 \\
k_{3}=-0.032 \pm 0.004 \\
k_{4}=-0.065 \pm 0.008 \\
k_{5}(\mathrm{II})=0.006 \pm 0.001\end{array}$ \\
\hline & $\begin{array}{l}\text { Quasi-eutonic } \\
\text { efflorescence (Ib) }\end{array}$ & $1.1-1.0$ & 4 & 0.99 & 6 & $k_{1}=1.01 \pm 0.03$ \\
\hline
\end{tabular}

thetic activity by the forest ecosystem, which depends on both temperature and solar radiation (Zhang et al., 2010; Miyazaki et al., 2012). Among these compounds are the highly water-soluble and hygroscopic isoprene-derived 2methyltetrols (Claeys et al., 2004; Ekström at al., 2009; Engelhart et al., 2011). Because solar radiation and the production of $\mathrm{OH}$ radicals are at a maximum in the tropics, the concentration of 2-methyltetrols in the Amazon Basin is higher than in boreal forests. The average concentration of 2-methyltetrols in Amazonian $\mathrm{PM}_{1}$ particles in the wet season is $45 \mathrm{ng} \mathrm{m}^{-3}$ (Decesari et al., 2006), while for the boreal ecosystem in the summertime it is only $\sim 26 \mathrm{ng} \mathrm{m}^{-3}$ (Kourtchev et al., 2005). Given that the WSOC / OC ratio for AMAZE and ZOTTO samples is comparable ( $63 \pm 4 \%)$, it seems possible, therefore, that the water uptake associated with WSOM in the AMAZE sample was higher than that in the ZOTTO sample.

Overall, the observed hygroscopicity behavior of the suband super-micron samples is consistent with their chemical composition. A twofold decrease in the dilute hygroscopicity parameter, $k_{6}=\kappa_{\mathrm{m}}^{0}$ (Table 3), and a reduction of the $\kappa_{\mathrm{m}}$ top value from $\sim 0.22$ (Fig. 8d) to $\sim 0.12$ (Fig. 8b) are consistent with a high fraction of organic carbon in the accumulation mode compared to the coarse mode. Likewise, the observed decrease in the quasi-eutonic efflorescence transition in the dehydration mode by $15 \%$ RH (i.e., the quasi-eutonic efflorescence transition is $\sim 50 \%$ RH in the coarse mode (Fig. $8 \mathrm{c}$ ) vs. $\sim 35 \%$ in the accumulation mode (Fig. 8a)) can also be associated with a high fraction of organic species in the accumulation mode.

In the internally mixed organic/inorganic particles the organic coating was found to decrease or even suppress the efflorescence of the inorganic salts (Choi and Chan, 2002; Brooks et al., 2003; Pant et al., 2004; Braban et al., 2004; Mikhailov et al., 2004; and Zardini et al., 2008), which can be explained by kinetic limitations caused by an ultra-viscous or gel-like or semi-solid organic matrix with low molecular diffusivity (Mikhailov et al., 2009; Shiraiwa et al., 2010) as will be discussed below. 
Table 4. Reconstructed neutral species concentrations $\left(\mathrm{ng} \mathrm{m}^{-3}\right)$ in the accumulation $(0.1-1 \mu \mathrm{m})$ and coarse $(>1 \mu \mathrm{m})$ size modes, their mass fraction $\left(f_{i}\right)$, volume fraction $\left(\varepsilon_{i}\right)$, density $\left(\rho_{\mathrm{d}, i}\right)$, and CCN-derived hygroscopicity $\left(\kappa_{\mathrm{v}, i}\right)$. The $\kappa_{\mathrm{v}, i}$ values in brackets were obtained under subsaturated conditions in the 96-99.4\% RH range. Uncertainties of all parameters for inorganic and carbonaceous compounds are estimated to be $\sim 10$ and $\sim 30 \%$, respectively. The subscript ws stands for parameters related to the water-soluble fraction.

\begin{tabular}{|c|c|c|c|c|c|c|c|c|c|}
\hline \multirow[t]{2}{*}{ Size mode } & \multirow[t]{2}{*}{ Parameters } & \multicolumn{8}{|c|}{ Chemical compounds } \\
\hline & & Nss- $\left(\mathrm{NH}_{4}\right)_{2} \mathrm{SO}_{4}$ & Sea salt & $\mathrm{NH}_{4} \mathrm{NO}_{3}$ & Nss- $\mathrm{K}_{2} \mathrm{SO}_{4}$ & $\mathrm{Nss}_{-} \mathrm{CaSO}_{4}$ & EC & WSOM & WIOM \\
\hline & $\rho_{\mathrm{d}, i}, \mathrm{~g} \mathrm{~cm}^{-3}$ & $1.77^{\mathrm{a}}$ & $2.24^{\mathrm{a}}$ & $1.73^{\mathrm{a}}$ & $2.66^{\mathrm{a}}$ & $2.96^{\mathrm{a}}$ & $2.0^{\mathrm{a}}$ & $1.4^{\mathrm{b}}$ & $1.4^{\mathrm{b}}$ \\
\hline & $\kappa_{\mathrm{v}, i}$ & $0.61^{\mathrm{c}}(0.57)^{\mathrm{g}}$ & $0.98^{\mathrm{d}}$ & $0.67^{\mathrm{c}}$ & $0.52^{\mathrm{e}}$ & $0.0016^{\mathrm{f}}$ & 0 & $0.1^{\mathrm{c}}(0.01-0.05)^{\mathrm{h}}$ & 0 \\
\hline \multirow[t]{5}{*}{ Accumulation } & $\mathrm{PM}\left(\mathrm{ng} \mathrm{m}^{-3}\right)$ & 544 & 7.7 & 0.5 & 45.4 & 3.9 & 17 & 830 & 146 \\
\hline & $f_{i}$ & 0.34 & $4.8 \times 10^{-3}$ & $3.2 \times 10^{-4}$ & 0.028 & $2.5 \times 10^{-3}$ & 0.011 & 0.52 & 0.091 \\
\hline & $\varepsilon_{i}$ & 0.30 & $3.3 \times 10^{-3}$ & $2.8 \times 10^{-4}$ & 0.016 & $1.3 \times 10^{-3}$ & $8.2 \times 10^{-3}$ & 0.57 & 0.10 \\
\hline & $f_{\mathrm{ws}, i}$ & 0.38 & $5.4 \times 10^{-3}$ & $3.6 \times 10^{-4}$ & 0.032 & - & - & 0.58 & - \\
\hline & $\varepsilon_{\mathrm{ws}, i}$ & 0.33 & $3.7 \times 10^{-3}$ & $3.2 \times 10^{-4}$ & 0.019 & - & - & 0.64 & - \\
\hline \multirow[t]{5}{*}{ Coarse } & $\mathrm{PM}\left(\mathrm{ng} \mathrm{m}^{-3}\right)$ & 241 & 33.3 & - & 21.5 & 23.7 & 3.3 & 41.2 & 155 \\
\hline & $f_{i}$ & 0.47 & 0.065 & - & 0.042 & 0.046 & $6.5 \times 10^{-3}$ & 0.080 & 0.30 \\
\hline & $\varepsilon_{i}$ & 0.44 & 0.048 & - & 0.026 & 0.026 & $5.3 \times 10^{-3}$ & 0.095 & 0.36 \\
\hline & $f_{\mathrm{ws}, i}$ & 0.72 & 0.10 & - & 0.064 & - & - & 0.12 & - \\
\hline & $\varepsilon_{\mathrm{ws}, i}$ & 0.72 & 0.080 & - & 0.043 & - & - & 0.16 & - \\
\hline
\end{tabular}

${ }^{\mathrm{a}}$ Lide (2005), density taken for $25^{\circ} \mathrm{C},{ }^{\mathrm{b}}$ Kostenidou et al. (2007), ${ }^{\mathrm{c}}$ Petters and Kreidenweis (2007), ${ }^{\mathrm{d}}$ Niedermier et al. (2008), ${ }^{\mathrm{e}}$ Kelly and Wexler (2006), ${ }^{\mathrm{f}}$ Sullivan et al. (2009),

$\mathrm{g}$ Mikhailov et al. (2013), ${ }^{\mathrm{h}}$ Petters et al. (2009).

\subsection{Dilute kappa composition closure}

Under the volume additivity assumption, the dilute hygroscopicity parameter $k_{6}=\kappa_{\mathrm{m}}^{0}$ can be converted to the Petters and Kreidenweis (2007) volume-based parameter, $\kappa_{\mathrm{v}}$, by the relation (Mikhailov et al., 2013)

$\kappa_{\mathrm{v}}=\kappa_{\mathrm{m}}^{0} \frac{\rho_{\mathrm{d}}}{\rho_{\mathrm{w}}}$.

Based on the ion balance from IC analysis (Table 2), we estimated the mass of neutral compounds in the accumulation and coarse size modes. In the mass balance of the neutral salt compounds we first distributed the measured concentrations of $\mathrm{Nss}_{-} \mathrm{SO}_{4}^{2-}$ and $\mathrm{NH}_{4}^{+}$ions (Table 2) between minor compounds: Nss-CaSO${ }_{4}, \mathrm{Nss}_{2} \mathrm{~K}_{2} \mathrm{SO}_{4}$, and $\mathrm{NH}_{4} \mathrm{NO}_{3}$. The remaining $\mathrm{SO}_{4}^{2-} / \mathrm{NH}_{4}^{+}$mass ratio was found to be 2.9 and 3.0 for accumulation and course mode, respectively. This is close to the sulfate / ammonium mass ratio in ammonium sulfate (AS), which is 2.7. The higher experimental ratio of ions as compared to the stoichiometric ratio in AS could be caused by letovicite (Mifflin et al., 2009) with a $\mathrm{SO}_{4}^{2-} / \mathrm{NH}_{4}^{+}$ratio of 3.6 or/and organosulfates (Hettiyadura et al., 2015), but these species can only account for a minor fraction because the ion balance shows that sulfate is almost fully neutralized by ammonium. Based on these calculations, we assume that ammonium sulfate is the main component among other possible ammoniated sulfate salts and sulfate containing organic species.

Reconstructed neutral species concentrations are shown in Table 4 with their mass fraction $\left(f_{i}\right)$, volume fraction $\left(\varepsilon_{i}\right)$, density $\left(\rho_{\mathrm{d}, i}\right)$, and hygroscopicity $\left(\kappa_{\mathrm{v}, i}\right)$. Using these parameters, the effective values of $\rho_{\mathrm{d}}$ and $\kappa_{\mathrm{v}, \mathrm{p}}$ for the ZOTTO samples have been computed by weighted averaging of the prop- erties of individual components:

$\rho_{\mathrm{d}}=\left(\sum_{i} \frac{f_{i}}{\rho_{i}}\right)^{-1}$,

$\kappa_{\mathrm{v}, \mathrm{p}}=\sum_{i} \varepsilon_{i} \kappa_{\mathrm{v}, i}$.

Equation (11) is the Zdanovskii, Stokes, and Robinson (ZSR) mixing rule (Petters and Kreidenweis, 2007) where $\kappa_{\mathrm{v}, \mathrm{p}}$ denotes the predicted $(p)$ hygroscopicity based on the volume fraction, $\varepsilon_{i}$, and the hygroscopicity, $\kappa_{\mathrm{v}, i}$, of the $i$ th component in the sample. From Eq. (10) and the $\rho_{i}, f_{i}$ pairs (Table 4) it follows that for submicron and supermicron particles the average weighted bulk densities are 1.54 and $1.66 \mathrm{~g} \mathrm{~cm}^{-3}$, respectively (Table 5). Inserting these values and the KIM-derived hygroscopicity parameters, $k_{6}=\kappa_{\mathrm{m}}^{0}$ (Table 3), into Eq. (9) yields $\kappa_{\mathrm{v}, \mathrm{t}}=0.094$ for the accumulation mode and $\kappa_{\mathrm{v}, \mathrm{t}}=0.21$ for the coarse mode (Table 5), where the subscript $(t)$ denotes the hygroscopicity related to the total dry particle mass.

As water-soluble compounds are the major contributors to hygroscopic growth, it is useful to further transcribe the original Eq. (2) as follows:

$G_{\mathrm{m}, \mathrm{ws}}=\frac{m_{\mathrm{w}}+m_{\mathrm{d}, \mathrm{ws}}}{m_{\mathrm{d}, \mathrm{ws}}}$,

where $G_{\mathrm{m} \text {,ws }}$ is the mass growth factor normalized to the mass of the neutral water-soluble (ws) compounds. Accordingly, the $G_{\mathrm{m} \text {,ws }}$ can be calculated from

$G_{\mathrm{m}, \mathrm{ws}}=\frac{1}{f_{\mathrm{ws}}}\left(G_{\mathrm{m}}-1\right)+1$, 
Table 5. Characteristic parameters obtained for the accumulation and coarse modes of ZOTTO samples: density $\left(\rho_{d}, \rho_{\mathrm{d}, \mathrm{ws}}\right)$ (Eq. 10), KIMderived $\left(\kappa_{\mathrm{m}}^{0}, \kappa_{\mathrm{m}, \mathrm{ws}}^{0}\right)$ and corresponding volume-based hygroscopicity parameters $\left(\kappa_{v, t}, \kappa_{\mathrm{v}, \mathrm{ws}}\right)$ (Eq. 9$)$, and mass fraction of water-soluble compounds $\left(f_{\mathrm{ws}}\right)$. Subscripts $t$ and ws stand for parameters related to total PM and to the water-soluble fraction, respectively. $\kappa_{\mathrm{V}, \mathrm{p}}$ is the predicted hygroscopicity based on the ZSR mixing rule (Eqs. 15, 16). For $\kappa_{\mathrm{m}}^{0}, \kappa_{\mathrm{m} \text {,ws }}^{0}$ uncertainties result from the goodness of the KIM fit. For the other parameters the propagated errors were calculated based on the total differential of a function by neglecting correlations between variables.

\begin{tabular}{lcccccccc}
\hline Size mode & \multicolumn{8}{c}{ Parameters } \\
\cline { 2 - 8 } & $\rho_{\mathrm{d}}, \mathrm{g} \mathrm{cm}^{-3}$ & $\kappa_{\mathrm{m}}^{0}$ & $\kappa_{\mathrm{v}, t}$ & $f_{\mathrm{ws}}$ & $\rho_{\mathrm{d}, \mathrm{ws}, \mathrm{g} \mathrm{cm}^{-3}}$ & $\kappa_{\mathrm{m}, \mathrm{ws}}^{0}$ & $\kappa_{\mathrm{v}, \mathrm{ws}}$ & $\kappa_{\mathrm{v}, \mathrm{p}}$ \\
\hline Accumulation & $1.54 \pm 0.09$ & $0.061 \pm 0.002$ & $0.094 \pm 0.006$ & $0.89 \pm 0.11$ & $1.55 \pm 0.11$ & $0.098 \pm 0.003$ & $0.15 \pm 0.01$ & $0.27 \pm 0.03$ \\
Coarse & $1.66 \pm 0.07$ & $0.128 \pm 0.004$ & $0.21 \pm 0.01$ & $0.66 \pm 0.08$ & $1.78 \pm 0.09$ & $0.20 \pm 0.01$ & $0.36 \pm 0.03$ & $0.53 \pm 0.05$ \\
\hline
\end{tabular}

where $f_{\mathrm{ws}}=m_{\mathrm{d}, \mathrm{ws}} / m_{\mathrm{d}}$ is the mass fraction of the watersoluble compounds in the PM, which is 0.89 and 0.66 for AM and CM, respectively. Using Eqs. (3) and (4) and the Kelvin correction algorithm (Mikhailov et al., 2013), we converted the $G_{\mathrm{m} \text {,ws }}$ RH pairs into $\kappa_{\mathrm{m} \text {,ws. The obtained dependencies }}$ of $\kappa_{\mathrm{m} \text {,ws }}$ on $G_{\mathrm{m} \text {,ws }}$ in the dilution regime and KIM fit lines (Eq. 8) are shown in Fig. 9. The corresponding best fit parameter (dilute hygroscopicity) $\kappa_{\mathrm{m}, \mathrm{ws}}^{0}=k_{6}$ for $\mathrm{AM}$ and $\mathrm{CM}$ and its volume-based derivative $\kappa_{\mathrm{v}, \mathrm{ws}}$ are given in Table 5. The volume-based hygroscopicity $\kappa_{\mathrm{v} \text {,ws }}$ was calculated from Eq. (9) as follows:

$\kappa_{\mathrm{v}, \mathrm{ws}}=\kappa_{\mathrm{m}, \mathrm{ws}}^{0} \times \rho_{\mathrm{d}, \mathrm{ws}} / \rho_{\mathrm{w}}$,

where $\rho_{\mathrm{d} \text {,ws }}$ is the average density of the water-soluble compounds in the dry particles, which was determined by inserting into Eq. (10) the mass fractions of water-soluble solutes, $f_{\mathrm{ws}, i}$ and $\rho_{\mathrm{d}, i}$ (Table 4).

As expected, the obtained $\kappa_{\mathrm{v}, \mathrm{ws}}$ is higher than $\kappa_{\mathrm{v}, \mathrm{t}}$ : the ratio $\kappa_{\mathrm{v}, \mathrm{ws}} / \kappa_{\mathrm{v}, \mathrm{t}}$ is approximately 1.6 for both size modes (Table 5). Since the hygroscopicity $\kappa_{\mathrm{v} \text {, ws }}$ accounts only for water-soluble species, the obtained values of 0.15 for AM and 0.36 for $\mathrm{CM}$ (Table 5) can be regarded as an upper limit characteristic of boreal aerosol particles in Siberia during the growing season. The $\kappa_{\mathrm{v} \text {,ws }}$ value of 0.15 obtained here for the accumulation mode is comparable to the $\mathrm{CCN}$-derived overall median value of $\kappa_{\mathrm{V}}=0.15$ reported by Gunthe et al. (2009) for tropical rainforest air during the wet season in central Amazonia and the average $\kappa_{\mathrm{V}}$ value of 0.16 measured by Levin et al. (2014) at a forested mountain site in Colorado from July to August. We are not aware of any other field data of $\kappa_{\mathrm{v}}$ for the coarse mode at remote continental sites, but the elevated CM value of 0.36 compared to that for the accumulation mode of 0.15 is consistent with the chemical analysis results, indicating a relatively high content of hygroscopic ammonium sulfate in $\mathrm{CM}\left(f_{\mathrm{ws}, \mathrm{AS}}=0.72 \mathrm{vs}\right.$. of 0.38 for AM) (Table 4).

We now compare the hygroscopicity $\kappa_{\mathrm{v}, \mathrm{ws}}$, estimated from FDHA measurements with the ZSR-predicted hygroscopicity, $\kappa_{\mathrm{v}, \mathrm{p}}$. Accounting for the fact that AS, WSOM, and sea salt are the main contributors to the hygroscopic growth (Table 4), Eq. (11) for AM and CM can be, respectively, reduced

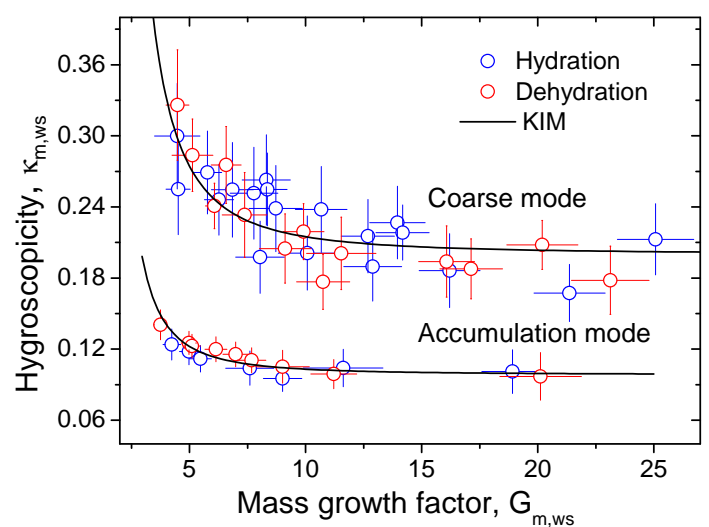

Figure 9. Mass-based hygroscopicity parameter $\kappa_{\mathrm{m}, \text { ws }}$ as a function of mass growth factor, $G_{\mathrm{m} \text {,ws }}$, normalized to water-soluble compounds (Eq. 12) upon hydration (blue) and dehydration (red). KIM fit of dilution mode, Eq. (8) - black solid line.

to

$$
\begin{aligned}
\kappa_{\mathrm{v}, \mathrm{p}}= & \kappa_{\mathrm{v}, \mathrm{AS}} \varepsilon_{\mathrm{ws}, \mathrm{AS}}+\kappa_{\mathrm{v}, \mathrm{WSOM}} \varepsilon_{\mathrm{ws}, \mathrm{WSOM}}, \\
\kappa_{\mathrm{v}, \mathrm{p}}= & \kappa_{\mathrm{v}, \mathrm{AS}} \varepsilon_{\mathrm{ws}, \mathrm{AS}}+\kappa_{\mathrm{v}, \text { sea salt }} \varepsilon_{\mathrm{ws}, \text { sea salt }} \\
& +\kappa_{\mathrm{v}, \mathrm{WSOM}} \varepsilon_{\mathrm{ws}, \text { WSOM }},
\end{aligned}
$$

where $\varepsilon_{\mathrm{ws}, i}$ is the volume fraction of water-soluble compounds scaled to total water-soluble PM (Table 4). The application of these simplified equations results in a $\sim 5 \%$ underestimation of $\kappa_{\mathrm{v}, \mathrm{p}}$ for both size modes.

The simple mixing rule (Eqs. 15, 16) with corresponding pairs of CCN-derived $\kappa_{\mathrm{v}, i}$ and $\varepsilon_{\mathrm{ws}, i}$ (Table 4) yields $\kappa_{\mathrm{v}, \mathrm{p}}=0.27$ for AM and $\kappa_{\mathrm{v}, \mathrm{p}}=0.53$ for CM. That is, the estimates from the mixing rule exceed the FDHA-derived $\kappa_{\mathrm{v} \text {,ws }}$ values (Table 5) by factors of 1.8 and 1.5 for the accumulation and coarse modes, respectively. The observed discrepancy is too large to be explained by experimental and PM chemical analysis uncertainties.

The high content of sparingly soluble organic matter produced by oxidation of biogenic emissions (Mikhailov et al., 2015) can account for the inconsistency between the ZSRpredicted $\kappa_{\mathrm{v}, \mathrm{p}}$ and FDHA-derived $\kappa_{\mathrm{v} \text {,ws }}$ values. In mixed particles the organic coating can reduce the water transport 
across the surface by acting as a physical barrier. Moreover, at high content of the sparingly soluble compounds this effect will strongly depend on the water activity range, as these species exhibit hygroscopic growth at $a_{\mathrm{w}}$ close to 1. This particularly leads to a discrepancy by a factor of 5-10 between SOA hygroscopicity determined from suband super-saturation experiments (Petters and Kreidenweis, 2007; Prenni et al., 2007; Wex et al., 2009; Petters et al., 2009; Pajunora et al., 2015). In our FDHA experiment the hygroscopicity, $\kappa_{\mathrm{m} \text {, ws }}^{0}$, was obtained in the dilution mode (Eq. 8) in the 96-99.4\% RH range. Depending on the type of SOA, the $\kappa_{\mathrm{v}}$ in a given RH range can vary from 0.01 to 0.05 (Wex et al., 2009; Petters et al., 2009), but it is still less than the values of $\kappa_{\mathrm{v}}=0.1 \pm 0.04$ obtained in CCN experiments (Petters and Kreidenweis, 2007; Gunthe et al., 2009; Wex et al.,2009; Chang et al., 2010; Engelhart et al., 2011). Thus, due to the uncertainty of $\kappa_{\mathrm{v}}$, the last term of Eqs. (15) and (16) can vary by a factor of 10 , which translates into 30 and $3 \%$ uncertainty in $\kappa_{\mathrm{v}, \mathrm{p}}$ for the accumulation mode and coarse mode, respectively. Nevertheless, this uncertainty does not cover the observed difference between the measured $\kappa_{\mathrm{v} \text {,ws }}$ and predicted $\kappa_{\mathrm{v}, \mathrm{p}}$ values. As mentioned above and as will be shown below for the internally mixed particles, the organic coating can limit the uptake of water by inorganic species and may thus decrease the hygroscopicity, especially in sub-saturated water vapor.

Based on the ZSR mixing rule (Eqs. 15 and 16), we can estimate the volume fraction of ammonium sulfate, $\varepsilon_{\mathrm{ws}, \mathrm{AS}, \mathrm{p}}$, that is involved in the hygroscopic growth. Inserting into Eq. (15) the KIM-derived $\kappa_{\mathrm{v} \text {, ws }}=0.15$ and experimental hygroscopicities $\kappa_{\mathrm{v}, \mathrm{AS}}=0.57, \kappa_{\mathrm{v}, \mathrm{WSOM}}=0.01$ and $0.05 \mathrm{ob}-$ tained for sub-saturated conditions at $96-99.4 \%$ RH (Table 4 , values are in brackets) yields for the accumulation mode $\varepsilon_{\mathrm{ws}, \mathrm{AS}, \mathrm{p}}=0.23 \pm 0.02$, while the total volume fraction $\varepsilon_{\mathrm{ws}, \mathrm{AS}}$ is 0.33 (Table 4). A similar calculation for the coarse mode using Eq. (16) with the KIM-derived $\kappa_{\mathrm{v} \text {,ws }}=0.36$ leads accordingly to $\varepsilon_{\mathrm{ws}, \mathrm{AS}, \mathrm{p}}=0.48 \pm 0.01$ vs. $\varepsilon_{\mathrm{ws}, \mathrm{AS}}=$ 0.72 (Table 4). Based on these estimations, one can assume that in sub-saturated conditions (96-99.4\% RH) the inorganic compounds were not completely dissolved: approximately 40 and $50 \%$ of ammonium sulfate in AM and CM, respectively, are isolated by sparingly soluble organic species, thereby reducing the hygroscopicity of the ZOTTO samples.

A similar positive difference (up to $77 \%$ ) between predicted (from chemical analysis) and $\mathrm{CCN}$-derived $\kappa_{\mathrm{v}}$ values was observed for pristine tropical rainforest aerosols studied during the AMAZE-08 campaign in central Amazonia (Gunthe et al., 2009). Although in the Amazon experiment the dry particle size range was $30-300 \mathrm{~nm}$, we do not exclude the possibility that the observed deviation was also caused by sparingly soluble SOA, which in the timescale of the CCN measurement (seconds or less) could impede the water transport to the more hygroscopic species like AS.
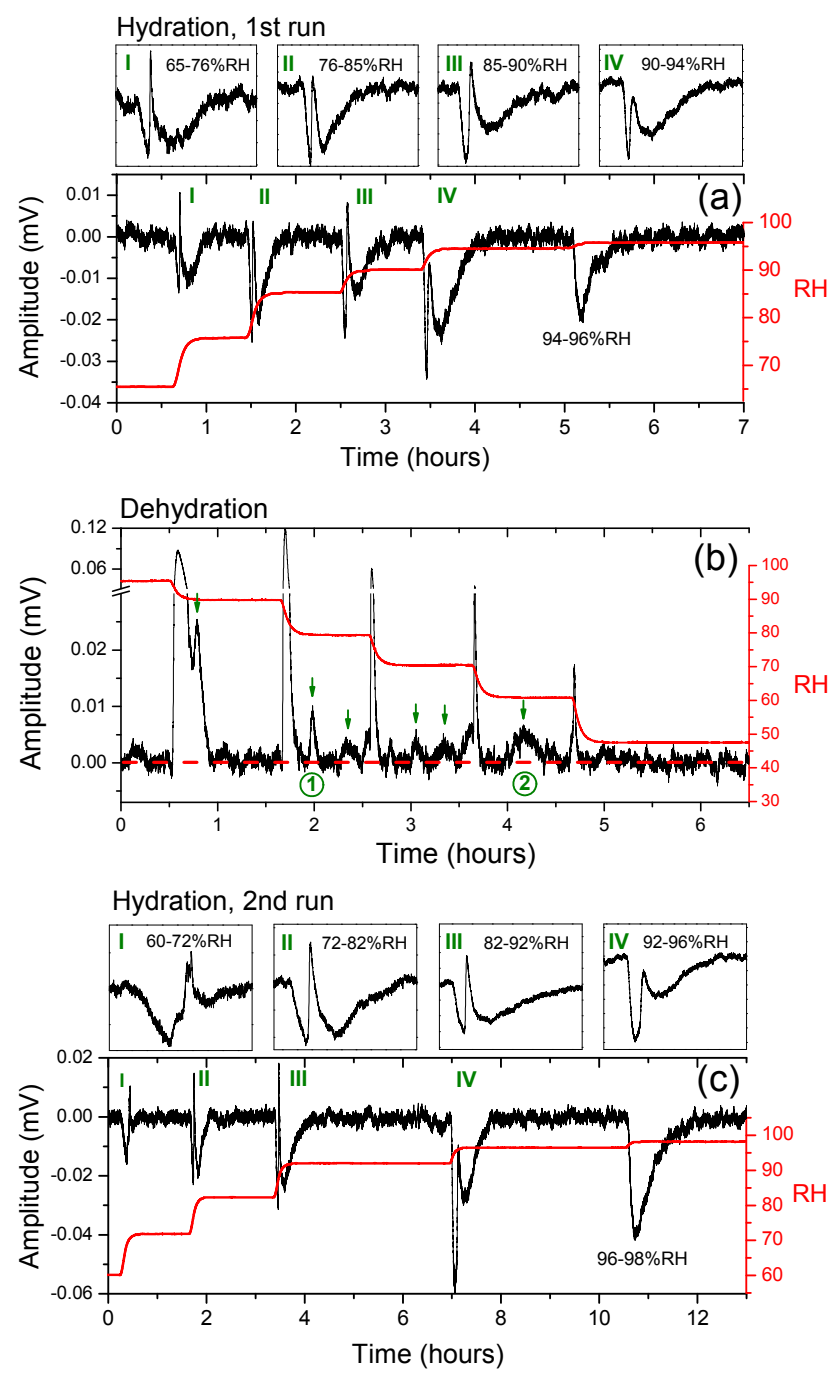

Figure 10. The water uptake diagram by the supermicron particles as a function of time during hydration $(\mathbf{a}, \mathbf{c})$ and dehydration (b) experiments. The red lines indicate the relative humidity $(\mathrm{RH})$ change. The red dashed line in panel (b) helps to guide the eye to see the changing trend of background amplitude. Explanation of other symbols is given in the text.

\subsection{Water uptake kinetics and microstructural rearrangements}

Figure 10 shows the raw data for hygroscopic cycles performed in the FDHA with the coarse-mode sample as a function of relative humidity. The areas under the peaks are proportional to the amount of the water that is absorbed (negative area) or released (positive area) upon particle hydration or dehydration. Figure 10a shows that at $60-94 \%$ RH during the first hydration cycle the water uptake is not a monotonic function of RH. The insets in panel (a) indicate that the water absorption is accompanied by partial evaporation. During the second humidifying run (Fig. 10c) the peak oscillations are observed again, and continue up to $\sim 96 \%$ RH. Figure $10 \mathrm{~b}$ 
shows that upon dehydration some peaks follow the relative humidity change almost instantaneously, while some other peaks appear with considerable delay, i.e., already at constant RH (marked with green arrows). Additionally, the width of these peaks characterizing the timescale of the dehydration process gradually increases with decreasing RH. Thus, at $79 \% \mathrm{RH}$ the water release takes $\sim 5 \mathrm{~min}$, whereas at $60 \%$ $\mathrm{RH}$ it lasts for $\sim 25 \mathrm{~min}$ : first and second peaks in Fig. 10c, respectively. This time is much more than the inherent response time of the FDHA system, which is $\sim 10 \mathrm{~s}$. The most plausible explanation for these observations is kinetic limitation by bulk diffusion in an amorphous (semi-)solid organic matrix, which inhibits uptake and release of water during hydration and dehydration cycles (Mikhailov et al., 2009).

As discussed in Sect. 4.2 and shown in Figs. 5 and 6, the internally mixed particles consist mainly of an inorganic core (mostly ammonium sulfate), surrounded by organic compounds. The STXM-NEXAFS results are consistent with the accompanying TEM investigations (Fig. 7), particularly indicating that the supermicron particles typically have an irregular porosity core embedded in an organic matrix. As noted above, the core of some of the particles has a pronounced dendritic structure (Fig. 7e-f). Such dendritic structures are characteristic of diffusion-limited growth processes (Feder, 1988).

The transport characteristics of water molecules through the organic coating can be estimated based on the following relation (Atkins, 1998):

$x=\left(4 D_{\mathrm{w}} \tau / \pi\right)^{\frac{1}{2}}$

where $x$ is the average distance traveled by water molecules diffusing in an organic shell, $\tau$ is the average time to travel over this distance, and $D_{\mathrm{w}}$ is the bulk diffusion coefficient of water. We chose for our calculations $x=0.2-0.5 \mu \mathrm{m}$ (i.e., the thickness of the organic shell of the particles shown in Fig. $7 \mathrm{~d}-\mathrm{f}$ ) and $\tau=1500 \mathrm{~s}$ at $60 \% \mathrm{RH}$ and $300 \mathrm{~s}$ at $79 \% \mathrm{RH}$, respectively. Using Eq. (10) for $x=0.2 ; 0.5 \mu \mathrm{m}$ we obtain $D_{\mathrm{w}}=2.1 \times 10^{-13} ; 1.3 \times 10^{-12} \mathrm{~cm}^{2} \mathrm{~s}^{-1}$ at $60 \% \mathrm{RH}$ and $1.0 \times$ $10^{-12} ; 6.5 \times 10^{-12} \mathrm{~cm}^{2} \mathrm{~s}^{-1}$ at $79 \% \mathrm{RH}$, respectively. These values are in the range of measured $D_{\mathrm{w}}$ in sucrose (Zobrist et al., 2011) and $D_{\mathrm{w}}$ in $\alpha$-pinene SOA estimated by percolation theory (Shiraiwa et al., 2013).

Low bulk diffusion coefficients suggest that organic coatings of the particles are in amorphous semi-solid states (Mikhailov et al., 2009; Koop et al., 2011; Shiraiwa et al., 2011). Moreover, the $D_{\mathrm{w}}$ value can be decreased by solidification and crust formation at the particle surface, which can strongly inhibit the interfacial transport of gas molecules (Pfrang et al., 2011). As noted in Sect. 4.2, a significant fraction $(\sim 20 \%)$ of the coarse-mode particles have this type of outer core (Fig. 7d-f), most likely formed as a result of liquid-liquid phase separation.

This is in good agreement with the observations that ambient particles in boreal forests bounce off the smooth hard surface of an impactor (Virtanen et al., 2010) and that the viscosity of laboratory-generated $\alpha$-pinene SOA is reported to be $10^{3}-10^{7} \mathrm{~Pa}$ s (Renbaum-Wolff et al., 2013). Additionally, the water release timescale of 300-1500 s observed in this study (Fig. 7b, peaks 1 and 2) is in reasonable agreement with model calculations for $\alpha$-pinene SOA+AS particles with core-shell structures (Shiraiwa et al., 2013), which predict at $60 \% \mathrm{RH}$ an e-folding time within $10^{1}-10^{3} \mathrm{~s}$ for $1 \mu \mathrm{m}$ particles and $10^{-4}-10^{0} \mathrm{~s}$ for the submicron fraction in the range of 30-100\% RH (Shiraiwa et al., 2013). These model results also help to explain why in the timescale of the FDHA experiment the kinetic limitations were observed for supermicron particles, but have not been detected for the particles in the accumulation mode.

From the FDHA-derived upper value of $D_{\mathrm{w}} \sim$ $10^{-12} \mathrm{~cm}^{2} \mathrm{~s}^{-1}$ and the typical particle size range of 20-200 nm used in HTDMA and CCNc instruments, it follows that the characteristic timescale for water diffusion into aerosol particles is 3-300 s (Eq. 17). These estimates are consistent with several HTDMA and CCNC studies where kinetic limitations have been observed due to organic coatings and the multi-second residence time used in these instruments (CCNC: Abbat et al., 2005; Henning et al., 2005; VanReken et al., 2005; Shants et al., 2010; Engelhart et al., 2008; Ruehl et al., 2009; HTDMA: Xiong et al., 1998; Chuang, 2003; Mikhailov et al., 2004; Sjogren et al., 2007).

As noted above and shown in Fig. 10a (inserts) during hydration cycles in the 60-96\% RH range, the water uptake is followed by a water release (negative peaks) despite growing RH. These observations can be explained by the complex morphology of the particles. Most likely at intermediate RHs due to partial dissolution, the different species become more mobile, which leads to compaction (restructuring) of the particles and release of excess water. The fact that in the second hydration cycle the water loss effect is reproducible (inserts in Fig. 10c) suggests that re-dried particles retained their irregular microstructure even at a drying rate as low as $\sim 0.4 \% \mathrm{RH} \mathrm{min}^{-1}$. The reproducibility of the irregular particle microstructure in subsequent hydrationdehydration cycles is in agreement with the earlier results of Zardini et al. (2008), who investigated laboratory-generated mixed AS-adipic acid particles by the electrodynamic balance (EDB) technique, and with recent STXM-NEXAFS results for Amazonian aerosol samples obtained by Pöhlker et al. (2014).

The driving forces of the morphological transformations can be an inverse Kelvin effect stimulating capillary condensation in the cracks, veins, and pores (Sjogren et al., 2007; Zardini et al., 2008; Mikhailov et al., 2004) and their subsequent collapse or/and Ostwald ripening, i.e., recrystallization that causes growth of large salt particles and shrinkage of smaller ones (Pöhlker et al., 2014). In our hydration experiments the water release peaks were observed up to $96 \% \mathrm{RH}$ (inserts in Fig. 10a, c), suggesting that morphology transfor- 
mations occurred with sparingly soluble species that restrain particle restructuring because of kinetic limitations.

In view of the results discussed above we suggest that boreal aerosol samples have complex morphologies. The organic material tends to be enriched at the particle surface and forms an envelope with low molecular diffusivity, which inhibits the access of water vapor to the particle core and leads to kinetic limitations. In the timescale of our FDHA experiment these kinetic limitations were clearly exhibited for supermicron particles in the hydration-dehydration cycles (Fig. 10), which resulted in a pronounced hysteresis effect (Fig. 8c).

\subsection{Summary and conclusions}

In this study, we have presented the hygroscopic properties of the accumulation and coarse modes of aerosol particles sampled at the ZOTTO background station in western Siberia during a summer campaign. The hygroscopic growth measurements were conducted with a filter-based differential hygroscopicity analyzer using the range of 5-99.4\% RH in the hydration and dehydration operation modes. These studies were complemented with chemical analyses of the samples, focusing on inorganic ions and organic carbon/elemental carbon. In addition, the microstructure and chemical composition of aerosol particles were analyzed by x-ray and electron microscopy techniques. The air-mass history, CO data, and chemical analysis results indicate background conditions during the sampling campaign.

The mass closure studies show that organic carbon accounted for 61 and $38 \%$ of PM in the accumulation mode (AM) and coarse mode (CM), respectively. Accordingly, the WSOM was estimated to be $\sim 52$ and $\sim 8 \%$. Sulfate, predominantly in the form of ammoniated sulfate, was the dominant inorganic component in both size modes: $~ 27 \%$ in the $\mathrm{AM}$ and $\sim 40 \%$ in the CM. Sea salt was the next abundant inorganic component, responsible for $\sim 6.6 \%$ of PM in the coarse mode. The bulk density of the dry particles was estimated to be $1.54 \pm 0.09$ and $1.66 \pm 0.07 \mathrm{~g} \mathrm{~cm}^{-3}$ for the AM and CM size mode, respectively.

The FDHA hygroscopic studies indicate that both AM and $\mathrm{CM}$ exhibit pronounced water uptake approximately at the same RH, starting at $\sim 70 \%$, while efflorescence occurred at different humidities, i.e., at $\sim 35 \% \mathrm{RH}$ for $\mathrm{AM}$ vs. $\sim 50 \%$ $\mathrm{RH}$ for $\mathrm{CM}$. This $\sim 15 \% \mathrm{RH}$ difference was attributed to a higher content of organic material in the sub-micron particles, which suppresses water release in the dehydration experiments. Overall, the observed hygroscopicity behavior of the sub- and super-micron samples is consistent with their chemical composition and microscopic structure. The relatively high content of organic carbon and low content of ammonium sulfate in AM as compared to CM cause at high RH an approximately twofold decrease in the water uptake. Thus, at $99 \% \mathrm{RH}$ the hygroscopic growth factor, $G_{\mathrm{m}}$, is $\sim 7.5$ and $\sim 13.4$ for sub- and super-micron particles, respectively.
The kappa mass interaction model (KIM) was applied to characterize non-ideal solution behavior and concentrationdependent water uptake by atmospheric aerosol samples with complex chemical composition. The $\kappa_{\mathrm{m}}$ model reproduces the FDHA mass water uptake results well and reveals three distinctly different regimes of hygroscopicity: (I) a quasieutonic deliquescence and efflorescence regime at low humidity, where substances are just partly dissolved and exist also in a non-dissolved phase; (II) a gradual deliquescence and efflorescence regime at intermediate humidity, where different solutes undergo gradual dissolution or solidification in the aqueous phase; and (III) a dilute regime at high humidity, where the solutes are fully dissolved, approaching their dilute hygroscopicity. The obtained KIM fit parameters can be used to characterize the hygroscopic behavior of sub- and super-micron boreal aerosols corresponding to background conditions in the growing season.

Based on KIM, for dilute aerosol solutions the volumebased hygroscopicity parameter, $\kappa_{\mathrm{V}}$, was calculated. The $\kappa_{\mathrm{V}}$ value normalized to total PM $\left(\kappa_{\mathrm{v}, \mathrm{t}}\right)$ and to the water-soluble fraction $\left(\kappa_{\mathrm{v}, \mathrm{ws}}\right)$ was estimated to be 0.098 and 0.15 for the accumulation mode and 0.21 and 0.36 for the coarse mode, respectively. These values can be regarded as the lower and upper limits of aerosol hygroscopicity in the background boreal environment. The measured value of $\kappa_{\mathrm{v}, \mathrm{ws}}=0.15$ for the accumulation mode is in good agreement with previously reported $\mathrm{CCN}$-derived data for remote sites in the Amazon forest $\left(\kappa_{\mathrm{V}} \approx 0.15\right)$ and the Colorado mountain forest $\left(\kappa_{\mathrm{V}} \approx 0.16\right)$.

The $\kappa_{\mathrm{v}, \mathrm{p}}$ values predicted from a chemical mass closure study (ZSR mixing rule) overestimate the FDHA-derived $\kappa_{\mathrm{v}, \mathrm{ws}}$ values by factors of 1.8 and 1.5 for the accumulation and coarse modes, respectively. The observed divergence can be explained by incomplete dissolution of the hygroscopic inorganic compounds due to kinetic limitations caused by a sparingly soluble organic coating. Supporting this assumption are the microstructural and kinetics measurement results. Thus, TEM and x-ray studies indicate predominantly core-shell structures of the aerosol particles with an inorganic core (mostly ammoniated sulfate) surrounded by organic compounds. The kinetic studies of the water release have shown that boreal aerosol particles enriched in organic species are in a semi-solid state, which is characterized by the diffusion coefficient $D_{\mathrm{w}} \sim 10^{-12} \mathrm{~cm}^{2} \mathrm{~s}^{-1}$.

In conclusion, the ZOTTO data set obtained in the growing season revealed a strong influence of biogenic organic carbon on the chemical composition and microstructure of the ambient aerosols. The sparingly soluble organic coating controls hygroscopic growth, phase transitions, and microstructural rearrangement processes in the ambient particles. The observed kinetic limitations in the water uptake can strongly influence the outcome of experiments performed on multisecond timescales, such as the commonly used HTDMA and CCNC instruments. 


\section{The Supplement related to this article is available online at doi:10.5194/acp-15-8847-2015-supplement.}

Acknowledgements. This work has been supported by the Max Planck Society (MPG), Saint Petersburg State University (grants 11.38.650.2013 and 11.42.1490.2015). We thank the Geomodel Research Center at Saint Petersburg State University for help with electron microscopy analysis and the team of the V. N. Sukachev Institute of Forest (SB RAS) for field support. The ALS is supported by the Director, Office of Science, Office of Basic Energy Sciences, of the US Department of Energy under contract DE-AC02-05CH11231. We thank the Helmholtz Center Berlin for the allocation of synchrotron radiation beamtime at BESSY II. We also thank Michael Bechtel for his constant support during the beamtime sessions.

The article processing charges for this open-access publication were covered by the Max Planck Society.

Edited by: A. Laskin

\section{References}

Abbatt, J. P. D., Broekhuizen, K., and Kumar, P. P.: Cloud condensation nucleus activity of internally mixed ammonium sulfate/organic acid aerosol particles, Atmos. Environ., 39, 47674778, 2005.

Andreae, M. O.: Aerosols before pollution, Science, 315, 50-51, 2007.

Andreae, M. O. and Rosenfeld, D.: Aerosol-cloud-precipitation interactions. Part 1. The nature and sources of cloud-active aerosols, Earth-Sci. Rev., 89, 13-41, 2008.

Andreae, M. O., Charlson, R. J., Bruynseels, F., Storms, H., Grieken, R. V., and Maenhaut, W.: Internal mixture of sea salt, silicates, and excess sulfate in marine aerosols, Science, 232, 1620-1623, 1986.

Atkins, P. W.: Physical Chemistry, Oxford University Press, Oxford, 1998.

Birch, M. E.: Analysis of carbonaceous aerosols: interlaboratory comparison, Analyst, 123, 851-857, 1998.

Birch, M. E. and Cary, R. A.: Elemental carbon-based method for monitoring occupational exposures to particulate diesel exhaust, Aerosol Sci. Technol., 25, 221-241, 1996.

Birmili, W., Stopfkuchen, K., Hermann, M., Wiedensohler, A., and Heintzenberg, J.: Particle penetration through a $300 \mathrm{~m}$ inlet pipe for sampling atmospheric aerosols from a tall meteorological tower, Aerosol Sci. Technol., 41, 811-817, 2007.

Birmili, W., Schwrin, K., Nowak, A., Petäjä, T., Joutsensaari, J., Rose, D., Wiedensohler, A., Hämeri, K., Aalto, P., Kulmala., M., and Boy, M.: Measurements of humidified size distribution in a Finish boreal forest: derivation of hygroscopic growth factors, Boreal Environ. Res., 14, 458-480, 2009.

Braban, C. F. and Abbatt, J. P. D.: A study of the phase transition behavior of internally mixed ammonium sulfate - malonic acid aerosols, Atmos. Chem. Phys., 4, 1451-1459, doi:10.5194/acp4-1451-2004, 2004.
Brooks, S. D., Garland, R. M., Wise, M. E., Prenni, A. J., Cushing, M., Hewitt, E., and Tolbert, M. A.: Phase changes in internally mixed maleic acid/ammonium sulfate aerosols., J. Geophys. Res., 108, 4487, doi:10.1029/2002JD003204, 2003.

Carslaw, K. S., Lee, L. A., Reddington, C. L., Pringle, K. J., Rap, A., Forster, P. M., Mann, G. W., Spracklen, D. V., Woodhouse, M. T., Regayre, L. A., and Pierce, J. R.: Large contribution of natural aerosols to uncertainty in indirect forcing, Nature, 503, 67-71, 2013.

Cerully, K. M., Raatikainen, T., Lance, S., Tkacik, D., Tiitta, P., Petäjä, T., Ehn, M., Kulmala, M., Worsnop, D. R., Laaksonen, A., Smith, J. N., and Nenes, A.: Aerosol hygroscopicity and CCN activation kinetics in a boreal forest environment during the 2007 EUCAARI campaign, Atmos. Chem. Phys., 11, 12369-12386, doi:10.5194/acp-11-12369-2011, 2011.

Chang, R. Y.-W., Slowik, J. G., Shantz, N. C., Vlasenko, A., Liggio, J., Sjostedt, S. J., Leaitch, W. R., and Abbatt, J. P. D.: The hygroscopicity parameter $(\kappa)$ of ambient organic aerosol at a field site subject to biogenic and anthropogenic influences: relationship to degree of aerosol oxidation, Atmos. Chem. Phys., 10, 5047-5064, doi:10.5194/acp-10-5047-2010, 2010.

Chang, R. Y.-W., Leck, C., Graus, M., Müller, M., Paatero, J., Burkhart, J. F., Stohl, A., Orr, L. H., Hayden, K., Li, S.-M., Hansel, A., Tjernström, M., Leaitch, W. R., and Abbatt, J. P. D.: Aerosol composition and sources in the central Arctic Ocean during ASCOS, Atmos. Chem. Phys., 11, 10619-10636, doi:10.5194/acp-11-10619-2011, 2011.

Chen, Q., Farmer, D. K., Schneider, J., Zorn, S. R., Heald, C. L., Karl, T. G., Guenther, A., Allan, J. D., Robinson, N., Coe, H., Kimmel, J. R., Pauliquevis, T., Borrmann, S., Pöschl, U., Andreae, M. O., Artaxo, P., Jimenez, J. L., and Martin, S. T.: Mass spectral characterization of submicron biogenic organic particles in the Amazon Basin, Geophys. Res. Lett., 36, L20806, doi:10.1029/2009gl039880, 2009.

Chuang, P. Y.: Measurement of the timescale of hygroscopic growth for atmospheric aerosols, J. Geophys. Res., 108, 4282, doi:10.1029/2002JD002757, 2003.

Choi, M. Y. and Chan, C. K.: The Effects of organic species on the hygroscopic behaviors of inorganic aerosols, Environ. Sci Technol., 36, 2422-2428, 2002.

Chi, X., Winderlich, J., Mayer, J.-C., Panov, A. V., Heimann, M., Birmili, W., Heintzenberg, J., Cheng, Y., and Andreae, M. O.: Long-term measurements of aerosol and carbon monoxide at the ZOTTO tall tower to characterize polluted and pristine air in the Siberian taiga, Atmos. Chem. Phys., 13, 12271-12298, doi:10.5194/acp-13-12271-2013, 2013.

Claeys, M., Graham, B., Vas, G., Wang, W., Vermeylen, R., Pashynska, V., Cafmeyer, J., Guyon, P., Andreae, M. O., Artaxo, P., and Maenhaut, W.: Formation of secondary organic aerosols through photooxidation of isoprene, Science, 303, 1173-1176, 2004.

Corrigan, A. L., Russell, L. M., Takahama, S., Äijälä, M., Ehn, M., Junninen, H., Rinne, J., Petäjä, T., Kulmala, M., Vogel, A. L., Hoffmann, T., Ebben, C. J., Geiger, F. M., Chhabra, P., Seinfeld, J. H., Worsnop, D. R., Song, W., Auld, J., and Williams, J.: Biogenic and biomass burning organic aerosol in a boreal forest at Hyytiälä, Finland, during HUMPPA-COPEC 2010, Atmos. Chem. Phys., 13, 12233-12256, doi:10.5194/acp13-12233-2013, 2013. 
Conard, S. G. and Ivanova, G. A.: Wildfire in Russian boreal forests- Potential impacts of fire regime characteristics on emissions and global carbon balance estimates, Environ. Pollut., 98, 305-313, 1997.

Decesari, S., Fuzzi, S., Facchini, M. C., Mircea, M., Emblico, L., Cavalli, F., Maenhaut, W., Chi, X., Schkolnik, G., Falkovich, A., Rudich, Y., Claeys, M., Pashynska, V., Vas, G., Kourtchev, I., Vermeylen, R., Hoffer, A., Andreae, M. O., Tagliavini, E., Moretti, F., and Artaxo, P.: Characterization of the organic composition of aerosols from Rondônia, Brazil, during the LBASMOCC 2002 experiment and its representation through model compounds, Atmos. Chem. Phys., 6, 375-402, doi:10.5194/acp6-375-2006, 2006.

Draxler, R. R. and Rolph, G. D.: HYSPLIT (HYbrid Single-Particle Lagrangian Integrated Trajectory) Model access via NOAA ARL READY Website (http://www.arl.noaa.gov/ready/hysplit4.html), NOAA Air Resources Laboratory, Silver Spring, MD, 2003.

Ehn, M., Petäjä, T., Aufmhoff, H., Aalto, P., Hämeri, K., Arnold, F., Laaksonen, A., and Kulmala, M.: Hygroscopic properties of ultrafine aerosol particles in the boreal forest: diurnal variation, solubility and the influence of sulfuric acid, Atmos. Chem. Phys., 7, 211-222, doi:10.5194/acp-7-211-2007, 2007.

Ekström, S., Nozière, B., and Hansson, H.-C.: The Cloud Condensation Nuclei $(\mathrm{CCN})$ properties of 2-methyltetrols and $\mathrm{C} 3-$ C6 polyols from osmolality and surface tension measurements, Atmos. Chem. Phys., 9, 973-980, doi:10.5194/acp-9-973-2009, 2009.

Engelhart, G. J., Asa-Awuku, A., Nenes, A., and Pandis, S. N.: CCN activity and droplet growth kinetics of fresh and aged monoterpene secondary organic aerosol, Atmos. Chem. Phys., 8, 39373949, doi:10.5194/acp-8-3937-2008, 2008.

Engelhart, G. J., Moore, R. H., Nenes, A. and Pandis, S. N.: Cloud condensation nuclei activity of isoprene secondary organic aerosol, J. Geophys. Res., 116, D02207, doi:10.1029/2010JD014706, 2011.

Feder, J.: Fractals, Plenum Press, New York, London, 1988.

Follath, R., Schmidt, J. S., Weigand, M., and Fauth, K.: The Xray microscopy beamline UE46-PGM2 at BESSY, in: Sri 2009: The 10th International Conference on Synchrotron Radiation Instrumentation, edited by: Garrett, R., Gentle I., Nugent K., and Wilkins S., AIP Conference Proceedings, 323-326, 2010.

Gong, S. L., Zhao, T. L., Sharma, S., Toom-Sauntry, D., Lavoue, D., Zhang, X. B., Leaitch, W. R., and Barrie, L. A.: Identification of trends and interannual variability of sulfate and black carbon in the Canadian High Arctic: 1981-2007, J. Geophys. Res., 115, D07305, doi:10.1029/2009jd012943, 2010.

Gunthe, S. S., King, S. M., Rose, D., Chen, Q., Roldin, P., Farmer, D. K., Jimenez, J. L., Artaxo, P., Andreae, M. O., Martin, S. T., and Pöschl, U.: Cloud condensation nuclei in pristine tropical rainforest air of Amazonia: size-resolved measurements and modeling of atmospheric aerosol composition and CCN activity, Atmos. Chem. Phys., 9, 7551-7575, doi:10.5194/acp-9-75512009, 2009.

Hämeri, K., Väkeva, M., Aalto, P. P., Kulmala, M., Swietlicki, E., Zhou, J., Seidl, W., Becker, E., and O'dowd, C. D.: Hygroscopic and CCN properties of aerosol particles in boreal forests, Tellus, 53B, 359-379, 2001.
Haywood, J. and Boucher, O.: Estimates of the direct and indirect radiative forcing due to tropospheric aerosols: A review, Rev. Geophys., 38, 513-543, 2000.

Heintzenberg, J., Birmili, W., Theiss, D., and Kisilyakhov, Y.: The atmospheric aerosol over Siberia, as seen from the $300 \mathrm{~m}$ ZOTTO tower, Tellus, 60B, 276-285, 2008.

Heintzenberg, J., Birmili, W., Otto, R., Andreae, M. O., Mayer, J.C., Chi, X., and Panov, A.: Aerosol particle number size distributions and particulate light absorption at the ZOTTO tall tower (Siberia), 2006-2009, Atmos. Chem. Phys., 11, 87038719, doi:10.5194/acp-11-8703-2011, 2011.

Henning, S., Rosenørn, T., D’ Anna, B., Gola, A. A., Svenningsson, B., and Bilde, M.: Cloud droplet activation and surface tension of mixtures of slightly soluble organics and inorganic salt, Atmos. Chem. Phys., 5, 575-582, doi:10.5194/acp-5-575-2005, 2005.

Hettiyadura, A. P. S., Stone, E. A., Kundu, S., Baker, Z., Geddes, E., Richards, K., and Humphry, T.: Determination of atmospheric organosulfates using HILIC chromatography with MS detection, Atmos. Meas. Tech., 8, 2347-2358, doi:10.5194/amt8-2347-2015, 2015

Jaatinen, A., Romakkaniemi, S., Anttila, T., Hyvärinen, A.-P., Hao, L.-Q., Kortelainen, A., Miettinen, P., Mikkonen, S., Smith, J. N., Virtanen, A., and Laaksonen, A.: The third Pallas Cloud Experiment: Consistency between the aerosol hygroscopic growth and CCN activity, Boreal Environ. Res., 19, 368-382, 2014.

Jaffrezo, J.-L., Aymoz, G., and Cozic, J.: Size distribution of EC and $\mathrm{OC}$ in the aerosol of Alpine valleys during summer and winter, Atmos. Chem. Phys., 5, 2915-2925, doi:10.5194/acp-52915-2005, 2005.

Kanakidou, M., Seinfeld, J. H., Pandis, S. N., Barnes, I., Dentener, F. J., Facchini, M. C., Van Dingenen, R., Ervens, B., Nenes, A., Nielsen, C. J., Swietlicki, E., Putaud, J. P., Balkanski, Y., Fuzzi, S., Horth, J., Moortgat, G. K., Winterhalter, R., Myhre, C. E. L., Tsigaridis, K., Vignati, E., Stephanou, E. G., and Wilson, J.: Organic aerosol and global climate modelling: a review, Atmos. Chem. Phys., 5, 1053-1123, doi:10.5194/acp-5-1053-2005, 2005.

Kelly, J. T. and Wexler, A. S.: Water uptake by aerosol: Water activityin supersaturated potassium solutions and deliquescence as a function of temperature, Atmos. Environ., 40, 4450-4468, 2006.

Kerminen, V.-M., Paramonov, M., Anttila, T., Riipinen, I., Fountoukis, C., Korhonen, H., Asmi, E., Laakso, L., Lihavainen, H., Swietlicki, E., Svenningsson, B., Asmi, A., Pandis, S. N., Kulmala, M., and Petäjä, T.: Cloud condensation nuclei production associated with atmospheric nucleation: a synthesis based on existing literature and new results, Atmos. Chem. Phys., 12, 12037 12059, doi:10.5194/acp-12-12037-2012, 2012.

Khlystov, A., Stanier, C., and Pandis, S. N.: An algorithm for combining electrical mobility and aerodynamic size distributions data when measuring ambient aerosol, Aerosol Sci. Technol., 38, 229-238, 2004.

Kilcoyne, A. L. D., Tyliszczak, T., Steele, W. F., Fakra, S., Hitchcock, P., Franck, K., Anderson, E., Harteneck, B., Rightor, E. G., Mitchell, G. E., Hitchcock, A. P., Yang, L., Warwick, T., and Ade, H.: Interferometer-controlled scanning transmission X-ray microscopes at the Advanced Light Source, J. Synchrot. Radiat., 10, 125-136, doi:10.1107/s0909049502017739, 2003.

Kiss, G., Varga, B., Galambos, I., and Ganszky, I.: Characterization of water-soluble organic matter isolated from 
atmospheric fine aerosol, J. Geophys. Res., 107, 8339, doi:10.1029/2001JD000603, 2002.

Koop, T., Bookhold, J., Shiraiwa, M., and Pöschl, U.: Glass transition and phase state of organic compounds: dependency on molecular properties and implications for secondary organic aerosols in the atmosphere, Phys. Chem. Chem. Phys., 13, 19238-19255, 2011.

Kourtchev, I., Ruuskanen, T., Maenhaut, W., Kulmala, M., and Claeys, M.: Observation of 2-methyltetrols and related photo-oxidation products of isoprene in boreal forest aerosols from Hyytiälä, Finland, Atmos. Chem. Phys., 5, 2761-2770, doi:10.5194/acp-5-2761-2005, 2005.

Kostenidou, E., Pathak, R. K., and Pandis, S. N.: An algorithm for the calculation of secondary organic aerosol density combining AMS and SMPS data, Aerosol Sci. Technol., 41, 1002-1010, 2007.

Leiva, M. A., Araya, M. C., Alvarado, A. M., and Seguel R. J.: Uncertainty estimation of anions and cations measured by ion chromatography in fine urban ambient particles (PM2.5), Accred Qual. Assur., 17, 53-63, 2012.

Levasseur, M.: Impact of Arctic meltdown on the microbial cycling of sulphur, Nature Geosci., 6, 691-670, 2013.

Levin, E. J. T., Prenni, A. J., Palm, B. B., Day, D. A., CampuzanoJost, P., Winkler, P. M., Kreidenweis, S. M., DeMott, P. J., Jimenez, J. L., and Smith, J. N.: Size-resolved aerosol composition and its link to hygroscopicity at a forested site in Colorado, Atmos. Chem. Phys., 14, 2657-2667, doi:10.5194/acp-14-26572014, 2014.

Li, S.-M. and Barrie, L. A.: Biogenic sulfur aerosol in the Arctic troposphere: 1. Contributions to total sulfate, J. Geophys. Res., 98, 20613-20622, 1993.

Lide, D. R.: CRC Handbook of Chemistry and Physics, 86th ed., CRC Press, Boca Raton, FL, 2005.

Liu, J., Bergin, M., Guo, H., King, L., Kotra, N., Edgerton, E., and Weber, R. J.: Size-resolved measurements of brown carbon in water and methanol extracts and estimates of their contribution to ambient fine-particle light absorption, Atmos. Chem. Phys., 13, 12389-12404, doi:10.5194/acp-13-12389-2013, 2013.

Maenhaut, W. and Claeys, M.: Characterisation and sources of carbonaceous atmospheric aerosols: final report, Brussels, Belgian Science Policy, 92 pp., 2007.

Maenhaut, W., Schwarz, J., Cafmeyer, J., and Chi, X. G.: Aerosol chemical mass closure during the EUROTRAC-2 AEROSOL Intercomparison 2000, Nucl. Instrum. Meth. B, 189, 233-237, 2002.

Maenhaut, W., Wang, W., and Chi, X.: Semivolatile behavior and filter sampling artifacts for dicarbocylic acids during summer campaigns at three forested sited in Europe, Boreal Environ. Res., 16, 273-287, 2011.

Marple, V. A., Rubow, K. L., and Behm, M.: A microorifice uniform deposit impactor (MOUDI): description, calibration, and use, Aerosol Sci. Technol., 14, 434-446, 1991.

McFiggans, G., Artaxo, P., Baltensperger, U., Coe, H., Facchini, M. C., Feingold, G., Fuzzi, S., Gysel, M., Laaksonen, A., Lohmann, U., Mentel, T. F., Murphy, D. M., O’Dowd, C. D., Snider, J. R., and Weingartner, E.: The effect of physical and chemical aerosol properties on warm cloud droplet activation, Atmos. Chem. Phys., 6, 2593-2649, doi:10.5194/acp-6-2593-2006, 2006.
Mifflin, A. L., Smith, M. L., and Martin, S. T.: Morphology hypothesized to influence aerosol particle deliquescence, Phys. Chem. Chem. Phys, 11, 10095-10107, 2009.

Mikhailov, E., Vlasenko, S., Niessner, R., and Pöschl, U.: Interaction of aerosol particles composed of protein and saltswith water vapor: hygroscopic growth and microstructural rearrangement, Atmos. Chem. Phys., 4, 323-350, doi:10.5194/acp-4-323-2004, 2004.

Mikhailov, E., Vlasenko, S., Martin, S. T., Koop, T., and Pöschl, U.: Amorphous and crystalline aerosol particles interacting with water vapor: conceptual framework and experimental evidence for restructuring, phase transitions and kinetic limitations, Atmos. Chem. Phys., 9, 9491-9522, doi:10.5194/acp-9-9491-2009, 2009.

Mikhailov, E. F., Merkulov, V. V., Vlasenko, S. S., Ryshkevich, T. I., and Pöschl, U. J.: Filter-based differential hygroscopicity analyzer of aerosol Particles, Izvestiya, Atmos. Ocean. Phys., 47, 747-759, 2011.

Mikhailov, E., Vlasenko, S., Rose, D., and Pöschl, U.: Mass-based hygroscopicity parameter interaction model and measurement of atmospheric aerosol water uptake, Atmos. Chem. Phys., 13, 717740, doi:10.5194/acp-13-717-2013, 2013.

Mikhailov, E., Mironova, S., Makarova, M., Vlasenko, S., Ryshkevich, T., Panov, A., and Andreae, M.: Seasonal variations of carbonaceous aerosol particles in Central Siberia, Izvestya Atmospheric and Oceanic Physics, 51, 422-429, 2015.

Miyazaki, Y., Jung, J., Fu, P., Mizoguchi, Y., Yamanoi, K., and Kawamura, K.: Evidence of formation of submicrometer water-soluble organic aerosols at a deciduous forest site in northern Japan in summer, J. Geophys. Res., 117, D19213, doi:10.1029/2012JD018250, 2012.

Moffet, R. C., Tivanski, A. V., and Gilles, M. K.: Fundamentals and Applications in Aerosol Spectroscopy, edited by: Signorell, R. and Reid, J., CRC, Boca Raton, FL, 2010.

Müller, D., Mattis, I., Wandinger, U., Ansmann, A., Althausen, D., and Stohl, A.: Raman lidar observations of aged Siberian and Canadian forest fire smoke in the free troposphere over Germany in 2003: Microphysical particle characterization, J. Geophys. Res., 110, D17201, doi:10.1029/2004JD005756, 2005.

Niedermeier, D., Wex, H., Voigtländer, J., Stratmann, F., Brüggemann, E., Kiselev, A., Henk, H., and Heintzenberg, J.: LACISmeasurements and parameterization of sea-salt particle hygroscopic growth and activation, Atmos. Chem. Phys., 8, 579-590, doi:10.5194/acp-8-579-2008, 2008.

Norman, A. L., Barrie, L. A., Toom-Sauntry, D., Sirois, A., Krouse, H. R., Li, S. M., and Sharma, S.: Sources of aerosol sulphate at Alert: Apportionment using stable isotopes: J. Geophys. Res., 104, 11619-11631, doi:10.1029/1999jd900078, 1999.

Ogren, J. and Charlson, J.: Implications for models and measurements of chemical inhomogeneities among cloud droplets, Tellus, 44B, 489-504, 1992.

Pajunoja, A., Lambe A. T., Hakala, J, Rastak, N., Cummings, M. J., Brogan, J. M., Hao, L., Paramonov, M., Hong, J., Prisle, N. L., Malila, J., Romakkaniemi, S., Lehtinen, K .E. J., Laaksonen, A., Kulmala, M., Massoli, P., Onasch T. B., Donahue, N. M., Riipinen, I., Davidovits, P., Worsnop, D. R., Petäjä, N., and Virtanen, A.: Adsorptive uptake of water by semisolid secondary organic aerosols, Geophys. Res. Lett., 42, 3063-3068, doi:10.1002/2015GL063142, 2015. 
Pant, A., Knopf, D. A., and Bertram, A. K.: Deliquescence and crystallization of ammonium sulfate particles internally mixed with water-soluble organic compounds, J. Phys. Chem. A, 108, 11600-11608, 2004.

Paramonov, M., Aalto, P. P., Asmi, A., Prisle, N., Kerminen, V.M., Kulmala, M., and Petäjä, T.: The analysis of size-segregated cloud condensation nuclei counter (CCNC) data and its implications for cloud droplet activation, Atmos. Chem. Phys., 13, 10285-10301, doi:10.5194/acp-13-10285-2013, 2013.

Petters, M. D. and Kreidenweis, S. M.: A single parameter representation of hygroscopic growth and cloud condensation nucleus activity, Atmos. Chem. Phys., 7, 1961-1971, doi:10.5194/acp-71961-2007, 2007.

Petters, M. D., Wex, H., Carrico, C. M., Hallbauer, E., Massling, A., McMeeking, G. R., Poulain, L., Wu, Z., Kreidenweis, S. M., and Stratmann, F.: Towards closing the gap between hygroscopic growth and activation for secondary organic aerosol - Part 2: Theoretical approaches, Atmos. Chem. Phys., 9, 3999-4009, doi:10.5194/acp-9-3999-2009, 2009.

Pfrang, C., Shiraiwa, M., and Pöschl, U.: Chemical ageing and transformation of diffusivity in semi-solid multi-component organic aerosol particles, Atmos. Chem. Phys., 11, 7343-7354, doi:10.5194/acp-11-7343-2011, 2011.

Pitman, R. M.: Wood ash use in forestry - a review of the environmental impacts, Forestry, 79, 563-588, doi:10.1093/forestry/cp1041, 2006.

Pöhlker, C., Wiedemann, K. T., Sinha, B., Shiraiwa, M., Gunthe, S. S., Smith, M., Su, H., Artaxo, P., Chen, Q., Cheng, Y., Elbert, W., Gilles, M. K., Kilcoyne, A. L. D., Moffet, R. C., Weigand, M., Martin, S. T., Pöschl, Ulrich, and Andreae, M. O.: Biogenic potassium salt particles as seeds for secondary organic aerosol in the Amazon, Science, 337, 1075-1078, doi:10.1126/science.1223264, 2012.

Pöhlker, C., Saturno, J., Krüger, M. L., Förster, J.-D., Weigand, M., Wiedemann, K. T., Bechtel, M., Artaxo, P., and Andreae, M. O.: Efflorescence upon humidification? X-ray microspectroscopic in situ observation of changes in aerosol microstructure and phase state upon hydration, Geophys. Res. Lett., 41, 36813689, doi:10.1002/2014GL059409, 2014.

Pöschl, U., Martin, S. T., Sinha, B., Chen, Q., Gunthe, S. S., Huffman, J. A., Borrmann, S., Farmer, D. K., Garland, R. M., Helas, G., Jimenez, J. L., King, S. M., Manzi, A., Mikhailov, E., Pauliquevis, T., Petters, M. D., Prenni, A. J., Roldin, P., Rose, D., Schneider, J., Su, H., Zorn, S. R., Artaxo, P., and Andreae, M. O.: Rainforest Aerosols as Biogenic Nuclei of Clouds and Precipitation in the Amazon, Science, 329, 15131516, doi:10.1126/science.1191056, 2010.

Prenni, A. J., Petters, M. D., Kreidenweis, S. M., DeMott, P. J., and Ziemann, P. J.: Cloud droplet activation of secondary organic aerosol, J. Geophys. Res.-Atmos., 112, D10223, doi:10.1029/2006JD007963, 2007.

Quinn, P. K., Miller, T. L., and Bates, I. S.: A 3-year record of simultaneously measured aerosol chemical and optical properties at Barrow, Alaska, J. Geophys. Res., 107, 4130, doi:10.1029/2001JD001248, 2002.

Rao, A. K. and Whitby K. T.: Non-ideal collection characteristics of inertial impactors - II. Cascade impactors, Aerosol Sci., 9, 87-100, 1978.
Rastak, N., Silvergren, S., Zieger, P., Wideqvist, U., Ström, J., Svenningsson, B., Maturilli, M., Tesche, M., Ekman, A. M. L., Tunved, P., and Riipinen, I.: Seasonal variation of aerosol water uptake and its impact on the direct radiative effect at Ny-Ålesund, Svalbard, Atmos. Chem. Phys., 14, 7445-7460, doi:10.5194/acp14-7445-2014, 2014.

Renbaum-Wolff, L., Grayson, J. W., Bateman, A. P., Kuwata, M., Sellier, M., Murray, B. J., Shilling, J. E., Martin, S. T., and Bertman A. K.: Viscosity of a-pinene secondary organic material and implications for particle growth and reactivity, P. Natl. Acad. Sci., 110, 8014-8019, 2013.

Riley, J. P. and Chester, R.: Introduction to Marine Chemistry, Academic, New York, 1971.

Ruehl, C. R. Chuang, P. Y., and Nenes A.: Distinct CCN activation kinetics above the marine boundary layer along the California coast, Geophys. Res, Lett., 36, L15814, doi:10.1029/2009GL038839, 2009.

Shantz, N. C., Chang, R. Y.-W., Slowik, J. G., Vlasenko, A., Abbatt, J. P. D., and Leaitch, W. R.: Slower CCN growth kinetics of anthropogenic aerosol compared to biogenic aerosol observed at a rural site, Atmos. Chem. Phys., 10, 299-312, doi:10.5194/acp10-299-2010, 2010

Shiraiwa, M., Pfrang, C., and Pöschl, U.: Kinetic multi-layer model of aerosol surface and bulk chemistry (KM-SUB): the influence of interfacial transport and bulk diffusion on the oxidation of oleic acid by ozone, Atmos. Chem. Phys., 10, 3673-3691, doi:10.5194/acp-10-3673-2010, 2010.

Shiraiwa, M., Ammann, M., Koop., T., and Pöschl, U.: Gas uptake and chemical aging of semisolid organic aerosol particles, P. Natl. Acad. Sci. USA, 108, 11002-11008, 2011.

Shiraiwa, M., Zuend, A., Bertram, A. K., and Seinfeld, J. H.: Gasparticle partitioning of atmospheric aerosols: interplay of physical state, non-ideal mixing and morphology, Phys. Chem. Chem. Phys., 15, 11441-11453, 2013.

Sihto, S.-L., Mikkilä, J., Vanhanen, J., Ehn, M., Liao, L., Lehtipalo, K., Aalto, P. P., Duplissy, J., Petäjä, T., Kerminen, V.-M., Boy, M., and Kulmala, M.: Seasonal variation of CCN concentrations and aerosol activation properties in boreal forest, Atmos. Chem. Phys., 11, 13269-13285, doi:10.5194/acp-11-13269-2011, 2011.

Sjogren, S., Gysel, M., Weingartner, E., Baltensperger, U., Cubison, M. J., Coe, H. Zardini, A. A., Marcolli, C., Krieger, U. K., and Peter, T.: Hygroscopic growth and water uptake kinetics of twophase aerosol particles consisting of ammonium sulfate, adipic and humic acid mixtures, Aerosol Sci., 38, 157-171, 2007.

Song, M., Marcolli, C., Krieger, U. K., Zuend, A., and Peter, T.: Liquid-liquid phase separation and morphology of internally mixed dicarboxylic acids/ammonium sulfate/water particles, Atmos. Chem. Phys., 12, 2691-2712, doi:10.5194/acp-12-26912012, 2012.

Soto-García, L. L., Andreae, M. O., Andreae, T. W., Artaxo, P., Maenhaut, W., Kirchstetter, T., Novakov, T., Chow, J. C., and Mayol-Bracero, O. L.: Evaluation of the carbon content of aerosols from the burning of biomass in the Brazilian Amazon using thermal, optical and thermal-optical analysis methods, Atmos. Chem. Phys., 11, 4425-4444, doi:10.5194/acp-11-44252011, 2011.

Spracklen, D. V. and Rap, A.: Natural aerosol-climate feedbacks suppressed by anthropogenic aerosol, Geophys. Res. Lett., 40, 5316-5319, doi:10.1002/2013GL057966, 2013. 
Ström, J., Umegard, J., Torseth, K., Tunved, P., Hansson, H. C., Holmen, K., Wismann, V., Herber, A., and König-Langlo, G.: One year of particle size distribution and aerosol chemical compo-sition measurements at the Zeppelin Station, Svalbard, March 2000-March 2001, Phys. Chem. Earth, 28, 1181-1190, doi:10.1016/j.pce.2003.08.058, 2003.

Sullivan, R. C., Moore, M. J. K., Petters, M. D., Kreidenweis, S. M., Roberts, G. C., and Prather, K. A.: Effect of chemical mixing state on the hygroscopicity and cloud nucleation properties of calcium mineral dust particles, Atmos. Chem. Phys., 9, 33033316, doi:10.5194/acp-9-3303-2009, 2009.

Swietlicki, E., Hansson, H.-C., Hämeri, K., Svenningsson, B., Massling, A., McFiggans, G., McMurry, P. H., Petäjä, T., Tunved, P., Gysel, M., Topping, D., Weingartner, E., Baltensperger, U., Rissler, J., Wiedensohler, A., and Kulmala M.: Hygroscopic properties of submicrometer atmospheric aerosol particles measured with H-TDMA instruments in various environments - a review, Tellus, 60B, 432-469, 2008.

Timonen, H., Saarikoski, S., Tolonen-Kivimäki, O., Aurela, M., Saarnio, K., Petäjä, T., Aalto, P. P., Kulmala, M., Pakkanen, T., and Hillamo, R.: Size distributions, sources and source areas of water-soluble organic carbon in urban background air, Atmos. Chem. Phys., 8, 5635-5647, doi:10.5194/acp-8-5635-2008, 2008.

Tunved, P., Hansson, H. C., Kerminen, V. M., Strom, J., Dal Maso, M., Lihavainen, H., Viisanen, Y., Aalto, P. P., Komppula, M., and Kulmala, M.: High natural aerosol loading over boreal forests, Science, 312, 261-263, 2006.

Twomey, S.: Atmospheric aerosols, Elsevier, New York, USA, 320 pp., 1977.

VanReken, T. M., Ng, N. L., Flagan, R. C., and Seinfeld, J. H.: Cloud condensation nucleus activation properties of biogenic secondary organic aerosol, J. Geophys. Res.-Atmos., 110, D07206, doi:10.1029/2004JD005465, 2005

Virtanen, A., Joutsensaari, J., Koop, T., Kannosto, J., Yli-Pirilä, P., Leskinen, J., Mäkelä, J. M., Holopainen, J. K., Pöschl, U., Kulmala, M., Worsnop, D. R., and Laaksonen, A.: An amorphous solid state of biogenic secondary organic aerosol particles, Nature, 467, 824-827, 2010.

Waggoner, A. P., Weiss, A. P., Ahlquist, N. C., Covert, D. S., and Charlson, R. J.: Optical characteristics of atmospheric aerosols, Atmos. Environ., 15, 1891-1909, 1981.
Walter, D. Heue, K.-P., Rauthe-Schöch, A., Brenninkmeijer, C. A. M. Lamsal, L. N., Krotkov, N. A., and Platt, U.: Flux calculation using CARIBIC DOAS aircraft measurements: $\mathrm{SO}_{2}$ emission of Norilsk, J. Geophys. Res., 117, D11305, doi:10.1029/2011JD017335, 2012.

Warneke, C., Bahreini, R., Brioude, J., Brock, C. A., de Gouw, J.A., Fahey, D. W., Froyd, K. D., Holloway, J. S., Middlebrook, A., Miller, L., Montzka, S., Murphy, D. M., Peischl, J., Ryerson, T. B., Schwarz, J. P., Spackman, J. R., and Veres, P: Biomass burning in Siberia and Kazakhstan as an important source for haze over the Alaskan Arctic in April 2008, Geophys. Res. Lett., 36, L02813, doi:10.1029/2008GL036194, 2009.

Wex, H., Petters, M. D., Carrico, C. M., Hallbauer, E., Massling, A., McMeeking, G. R., Poulain, L., Wu, Z., Kreidenweis, S. M., and Stratmann, F.: Towards closing the gap between hygroscopic growth and activation for secondary organic aerosol: Part $1-$ Evidence from measurements, Atmos. Chem. Phys., 9, 3987-3997, doi:10.5194/acp-9-3987-2009, 2009.

Wexler, A. S. and Seinfeld, J. H.: Second-generation inorganic aerosol model, Atmos. Environ., 25A, 2731-2748, doi:10.1016/0960-1686(91)90203-J, 1991.

Winderlich, J., Chen, H., Gerbig, C., Seifert, T., Kolle, O., Lavric, J. V., Kaiser, C., Höfer, A., and Heimann, M.: Continuous lowmaintenance $\mathrm{CO}_{2} / \mathrm{CH}_{4} / \mathrm{H}_{2} \mathrm{O}$ measurements at the Zotino Tall Tower Observatory (ZOTTO) in Central Siberia, Atmos. Meas. Tech., 3, 1113-1128, doi:10.5194/amt-3-1113-2010, 2010.

Xiong, J. Q., Zhong, M. H., Fang, C. P., Chen, L. C., and Lippmann, M.: Influence of organic films on hygroscopicity of ultrafine sulfuric acid aerosol, Environ. Sci. Technol., 32, 3536-3541, 1998.

Zardini, A. A., Sjogren, S., Marcolli, C., Krieger, U. K., Gysel, M., Weingartner, E., Baltensperger, U., and Peter, T.: A combined particle trap/HTDMA hygroscopicity study of mixed inorganic/organic aerosol particles, Atmos. Chem. Phys., 8, 55895601, doi:10.5194/acp-8-5589-2008, 2008.

Zhang, Y. Y., Müller, L., Winterhalter, R., Moortgat, G. K., Hoffmann, T., and Pöschl, U.: Seasonal cycle and temperature dependence of pinene oxidation products, dicarboxylic acids and nitrophenols in fine and coarse air particulate matter, Atmos. Chem. Phys., 10, 7859-7873, doi:10.5194/acp-10-7859-2010, 2010.

Zobrist, B., Soonsin, V., Luo, B. P., Krieger, U. K., Marcolli, C., Peter, T., and Koop, T.: Ultra-slow water diffusion in aqueous sucrose glasses, Phys. Chem. Chem. Phys., 13, 3514-3526, 2011. 